\title{
Effects of Breccia and Water Contents on the Mechanical Properties of Fault-core-zone Materials: an Experimental Investigation Using Artificial Specimens
}

Hyun-Seok Yun

KEPCO Engineering \& construction

\section{Seong-Woo Moon}

Chungbuk National University

Yong-Seok Seo (Dysseo@cbu.ac.kr)

Chungbuk National University

\section{Research Article}

Keywords: UCS, PRV, elastic modulus, High coefficients, potentially useful parameters

Posted Date: January 6th, 2022

DOI: https://doi.org/10.21203/rs.3.rs-1223193/v1

License: (c) (1) This work is licensed under a Creative Commons Attribution 4.0 International License.

Read Full License 


\title{
Effects of Breccia and Water Contents on the Mechanical Properties of Fault-core-zone Materials: An Experimental Investigation using Artificial Specimens
}

\author{
Hyun-Seok Yun ${ }^{1}$, Seong-Woo Moon², Yong-Seok Seo²*
}

\begin{abstract}
${ }^{1}$ Civil and Architectural, Environmental Engineering Department, KEPCO Engineering \& Construction, Gimcheon 39660, Republic of Korea

2Department of Earth and Environmental Sciences, Chungbuk National University, Cheongju 28644, Republic of Korea

*e-mail: ysseo@cbu.ac.kr
\end{abstract}

\section{ABSTRACT}

Determining the mechanical properties of fault-core-zone materials is challenging because of the low strength of such materials, which affects field sampling, specimen preparation, and laboratory testing. We overcame this problem by preparing and testing mechanical properties of 132 artificial fault-corezone specimens consisting of mixtures of breccia, sand, clay, and water. The unconfined compressive strength (UCS), elastic modulus (E), and penetration resistance value (PRV) of these fault-core-zone materials were measured, and the effects of breccia content and water content on mechanical properties were assessed. Results show that UCS is inversely proportional to breccia content and water content, and that $E$ is inversely proportional to water content. Furthermore, the inverse relationship of UCS with water content varies with breccia content. UCS is proportional to both PRV and E, and the relationship for each varies with breccia content. High coefficients of determination $\left(R^{2}=0.62-0.88\right)$ between the parameters suggest that breccia content, water content, and PRV are potentially useful parameters for estimating the mechanical properties of fault core zones.

\section{Introduction}

A fault core zone consists of gouge (or clay), cataclasite, and breccia, and is a zone of intense deformation surrounded by a fault damage zone $\mathrm{e}^{1-10}$. Fault core zones, also termed fault-slip zones, accommodate most of the displacement during faulting, causing the existing material to be crushed and altered ${ }^{11}$. As fault-core-zone material (hereinafter referred to as the "fault core") has lower strength than the surrounding rock mass, it is classified as critical geomaterial that can cause geotechnical problems in rock engineering projects ${ }^{12-16}$. Therefore, it is very important to clearly understand and determine the physico-mechanical properties of fault core. However, to determine the mechanical properties of fault-core, high-quality samples are needed ${ }^{17}$. Unfortunately, the weakness 
of such materials and the alignment of constituent particles mean that sampling in the field and sample preparation for laboratory testing are challenging and often compromised or unsuccessful ${ }^{18-20}$. Kanji ${ }^{21}$ explained that it is difficult to test using typical sampling, site investigation, and rock mechanics equipment. These problems regarding the characteristics of the fault core, together with high levels of material heterogeneity because of differing host rock types and fault displacement histories, means that geotechnical properties are likely to show wide variance ${ }^{15}$. These characteristics can in turn lead to high project costs because they encourage engineers to apply conservative parameters in design and construction ${ }^{14,21,22}$.

Previous studies of the physico-mechanical properties of fault cores have focused mostly on analysis of the frictional behavior of clay-rich gouge ${ }^{23-29}$. In particular, the shear characteristics of fault core, such as coefficients of friction using shear tests ${ }^{30-32}$ and correlations between particle characteristics (e.g., size) and shear strength ${ }^{33-}$ ${ }^{37}$, have been investigated more often than other properties (e.g., unconfined compressive strength (UCS) and elastic modulus (E)) because of the easier sampling and specimen preparation involved. On the other hand, previous analyses for UCS and E have limited on soft rocks (e.g., fault rocks, coarse pyroclastics, sheared serpentinites, and mélanges including gouge, clay, and breccia) which specimens shaping is possible on ${ }^{16,38-43}$. Kahraman and Alber ${ }^{14}$ found a strong correlation between volumetric block proportion (VBP) and UCS in strength testing of fault breccia samples. Sonmez et al. ${ }^{44,45}$ also established a relationship between UCS and VBP in strength tests of Ankara agglomerate. Kahraman et al. ${ }^{17}$ found a correlation between UCS and S-wave velocity by testing fault breccia collected from the Misis Fault in Turkey and developed a multiple regression model to predict UCS and differential stress $(\Delta \sigma)$ using density, P- and S-wave velocity, and textural properties. Chang et al. ${ }^{46}$ and $\mathrm{Kanji}^{21}$ analyzed data for various soft rocks and established that UCS is inversely proportional to water content and proportional to $\mathrm{E}\left(\mathrm{E}_{50}\right.$, the modulus at $50 \%$ ultimate strength). In addition, using the results of Kanji ${ }^{21,47}$ and Kanji and Galván ${ }^{48}$ identified an S-shaped relationship between dry density and UCS on a semi-log scale.

To overcome the difficulties of sampling and preparing specimens of fault core for conventional geomechanics tests, some studies have attempted to measure mechanical properties using such approaches as testing artificial specimens ${ }^{20,49-51}$, using simpler tests and equipment ${ }^{19,20,52-56}$, and applying statistical/modeling techniques such as regression analysis, fuzzy logic, and neural networks ${ }^{57-63}$. Measuring the physico-mechanical properties of artificial specimens has the advantage of being able to control some parameter values and experimental conditions $^{51}$, and previous studies using this approach have yielded meaningful results in terms of the characteristics of natural rocks ${ }^{49,64}$. Simple tests such as the needle penetration test (NPT), Schmidt hammer test, point load test, Shore hardness index, and block punch strength index all have the advantage of simple specimen preparation compared with tests of UCS and $E^{19,20}$. In addition, statistical and modeling methods have the advantage of being able to estimate the mechanical properties using multiple factors. Although these various approaches and tests can provide reasonably reliable results and yield a better understanding of the physicomechanical properties of soft materials, few studies have been conducted on fault cores.

In this study, we conducted laboratory tests on artificial specimens to investigate the physico-mechanical properties of fault core, natural examples of which are difficult to sample in the field. We prepared 132 artificial specimens comprising mixtures of different proportions of breccia, sand, clay, and water. Unconfined 
compression tests and penetration resistance tests were conducted on these artificial specimens, and their mechanical properties (UCS, E, and penetration resistance value (PRV)) were calculated. The data were analyzed to quantify the effects of breccia content and water content on mechanical properties as well as to establish relationships (correlations) between factors related to the mechanical properties of fault core.

\section{Preparation of artificial specimens}

Materials. Artificial specimens were made by mixing breccia, sand, and clay, which are the major components of fault core, with water. No bonding materials were added so as to more closely simulate natural fault material. The breccia used was obtained from the Ocheon Fault Zone in southeastern Korea (Fig. 1a). The Ocheon Fault Zone is a representative fault zone of the area and has been active during the Cenozoic ${ }^{65,66}$. The host bedrock of this fault zone is mainly granite, with lesser granodiorite and andesite. For this study, breccia was classified as particle sizes of $\geq 4.75 \mathrm{~mm}$ (sieve \#4) after sampling numerous fault core materials along this fault (Fig. 1b). In geology, breccia size has been defined differently by various investigators, over a wide range from 0.1 to $5.0 \mathrm{~mm}^{67-73}$. Here, the size was based on the internationally recognized unified soil classification system (USCS) by American Society for Testing and Materials (ASTM 2487-17) ${ }^{74}$, which is commonly used in soil mechanics and rock engineering projects. Sand was classified as falling betwen sieves \#4 and \#200 (4.75 mm $\geq$ particle size $\geq 0.075 \mathrm{~mm}$ ).

Clay $(<0.075 \mathrm{~mm})$ is not always present in large volumes in outcrops of fault materials, and it is difficult to extract only clay from fault core zone. Accordingly, for the present study, ceramics clay was used as the clay material in the manufacture of artificial specimens. The major mineral compositions of the clay material used, as analyzed by X-ray diffraction (XRD), are quartz (34.3 vol.\%), albite (18.6 vol.\%), kaolinite (14.7 vol.\%), and microcline (11.4 vol.\%) (Fig. 2, Table 1). Figure 3 shows box-and-whisker plots comparing the mineral contents of the clay material used and 40 fault-core-zone clays (sampled from outcrops of the several fault zones in southeastern Korea). The mineral contents of the clay material used in this study lie mostly within the interquartile range of the natural fault-core-zone clays, and there is no statistically significant difference between the mean or median mineral contents of the clay material and the fault-core-zone clays. Consequently, the mineralogy of the clay material used in the artificial specimens was highly similar to that of fault-core-zone clays sampled from the field.

Determination of mixture component ratios. The mixing ratios of materials in the artificial specimens were determined by sampling and particle-size analysis of natural fault cores (a total of 96 material samples). Particles of the constituent components were classified into breccia $(\geq 4.75 \mathrm{~mm})$, sand $(0.075-4.75 \mathrm{~mm})$, and clay $(<0.075 \mathrm{~mm})$. The sieve test method of ASTM D422-6375 was applied simultaneously with the soilwashing test method of ASTM D1140-1776 to clearly separate the components in the natural fault core.

Results of the particle-size analysis showed that breccia constituted $0-45 \mathrm{wt} . \%$ of the total material, mainly 0 5 wt.\% (Fig. 4a). Sand and clay contents varied from 0 to 100 wt.\%, but mainly $45-65$ and 30-35 wt.\%, 
respectively (Fig. 4b, c). On the basis of these results, the component mixing ratios for the artificial specimens were determined in terms of a $20 \mathrm{wt}$ \% interval with ranges of 0-40 wt.\% breccia, 0-60 wt.\% sand, and 20-100 wt.\% clay, with 11 types of specimen consequently being manufactured (Table 2).

Manufacture of artificial specimens. For manufacturing the artificial specimens, breccia, sand, and clay were prepared in appropriate quantities for the mixing ratios listed in Table 2 and mixed with water (Fig. 5a). The resultant materials were compacted for $>2 \mathrm{~h}$ to generate a degree of cohesion/bonding within them. Artificial specimens were formed as cylinders by inserting an acrylic tube into the compacted materials for subsequent unconfined compression tests and penetration resistance tests (Fig. 5b). The diameter and length of the cylindrical specimens were $6 \mathrm{~cm}$ and $14 \mathrm{~cm}$, respectively, following ASTM D2166-16 ${ }^{77}$. Twelve specimens (i.e., two specimens at each of the six water contents, one for unconfined compression tests and one for penetration resistance tests) were prepared at each of the eleven mixing ratios (S-1 to S-11) listed in Table 2, giving a total of 132 specimens. Drying times were set at $0,12,24,36,48$, or $72 \mathrm{~h}$ to produce specimens with six different water contents. Drying was performed at $40{ }^{\circ} \mathrm{C}$ to minimize the chemical change of clay minerals that might otherwise have occurred at higher temperatures (Fig. 5c).

\section{Experiments}

Calculation of water content Water content is generally calculated from the mass of water $\left(\mathrm{M}_{\mathrm{w}}\right)$ of the moist specimen and the mass of the completely dried specimen $\left(\mathrm{M}_{\mathrm{cds}}\right)^{78}$. However, during the present study it is impossible to measure $\mathbf{M}_{\mathrm{w}}$ or $\mathbf{M}_{\mathrm{cds}}$ because the specimens are destroyed as a result of unconfined compression tests being conducted before complete dryness. Therefore, water contents were calculated indirectly as a function of the masses of specimens dried for $72 \mathrm{~h}$. Figure 6 shows the change in mass by drying time of specimens dried for $72 \mathrm{~h}$ at each mixing ratio. The mass of specimens decreases rapidly during the first part of drying and becomes almost constant after $\sim 65 \mathrm{~h}$. We infer that the specimens were almost completely dried after $72 \mathrm{~h}$ of drying. Thus, the initial water content $\left(\omega_{\mathrm{i}}\right)$ of these specimens before oven drying can be calculated by Eq. $(1)^{78}$.

$$
\omega_{i}=\frac{M_{m s}-M_{c d s}}{M_{c d s}} \times 100=\frac{M_{w}}{M_{c d s}} \times 100
$$

where $\omega_{\mathrm{i}}$ is the initial water content of the moist specimen before oven drying $(\%), \mathrm{M}_{\mathrm{ms}}$ is the mass of the moist specimen before oven drying $(\mathrm{g}), \mathrm{M}_{\mathrm{cds}}$ is the mass of a completely dried specimen (after $72 \mathrm{~h}$ of drying time) (g), and $M_{w}$ is the total mass of water within a moist specimen calculated from $M_{m s}$ and $M_{c d s}(g)$.

Furthermore, each $\omega_{\mathrm{i}}$ of these specimens should be equal to those of other specimens (dried for $0,12,24,36$, or $48 \mathrm{~h}$ ) with the same constituent component ratio because they were manufactured under the same conditions. Thus, the $\mathrm{M}_{\mathrm{w}}$ of the specimens (dried for 0,12,24,36, or $48 \mathrm{~h}$ ) can be calculated by Eq. (3), which is derived from Eqs. (1) and (2). 


$$
\begin{aligned}
& M_{c d s}=M_{m s}-M_{w} \\
& M_{w}=\frac{M_{m s} \times \omega_{i}}{1+\omega_{i}}
\end{aligned}
$$

where the $\mathrm{M}_{\mathrm{w}}$ of each specimen (dried for $0,12,24,36$, or $48 \mathrm{~h}$ ) is calculated from $\omega_{\mathrm{i}}$ of a specimen dried for 72 $\mathrm{h}$ with the same proportions of constituent components.

Consequently, the water content $(\omega)$ of each specimen was calculated from Eq. (4) by measuring its mass before and after drying, and these water contents are given in Table 3.

$$
\omega=\frac{M_{w d}}{M_{c d s}} \times 100=\frac{M_{m s}-M_{d s}}{M_{m s}-M_{w}} \times 100
$$

where $\omega$ is the water content of an oven-dried specimen $(\Delta \%), M_{w d}$ is the mass of remaining water within an ovendried specimen $(\mathrm{g})$, and $\mathrm{M}_{\mathrm{ds}}$ is the mass of an oven-dried specimen $(\mathrm{g})$.

Unconfined compression tests. Unconfined compression tests were conducted to determine the UCS and $\mathrm{E}$ of each specimen (Fig. 7). Tests were conducted using equipment with a maximum load capacity of $50 \mathrm{kN}$. Loads were applied at a fixed rate of displacement of $1.0 \mathrm{~mm} / \mathrm{min}$. Axial strain and load were recorded at $0.2 \mathrm{~s}$ intervals, and loading continued until the compressive stress decreased after failure or the strain reached $15 \%{ }^{77}$. Values of UCS and E (secant modulus at 50\% ultimate strength $\left(\mathrm{E}_{\mathrm{s} 50}\right)$ and tangent modulus at $50 \%$ ultimate strength $\left.\left(\mathrm{E}_{\mathrm{t} 50}\right)\right)$ were determined from the measured stress-strain curves following International Society for Rock Mechanics and Rock Engineering ${ }^{79}$.

Unconfined compression test results show that failure did not occur in specimen sets (a) or (b), which have higher water contents compared with other specimens, with only plastic deformation being observed (Fig. 8a). In contrast, specimen sets (c) to (f), with higher water contents, showed a failure mode similar to that of rock (Fig. 8b). Failure planes for specimens containing breccia occurred mostly along breccia boundaries (Fig. 9). Such failure planes typically appear when either the breccia-matrix contact is weak or the matrix itself is weak ${ }^{14,17}$.

Typical stress-strain curves (for specimen set S-6) for each water content (drying time) are shown in Fig. 10. Both UCS and slope (E) in the stress-strain curves increase as water content decreases (from S-6a to S-6f). Also, specimens S-6a-b, which have higher water contents compared with other specimens, show continuous creep behavior as strain increases. In contrast, specimen S-6f, with the lowest water content, shows elastic-plastic deformation with increasing strain. Specimens S-6c-e show plastic-elastic-plastic deformation ${ }^{80}$. Values of UCS and $\mathrm{E}$ of each tested specimen, as determined from the stress-strain curves, are given in Table 4.

Penetration resistance tests. Penetration resistance tests were conducted on the artificial specimens 
to establish whether this simpler test could be used as a proxy for unconfined compression testing of natural fault core, which, as mentioned, is challenging in terms of specimen sampling and preparation. The penetration resistance test is also less time-consuming and less costly than unconfined compression testing and is a non-

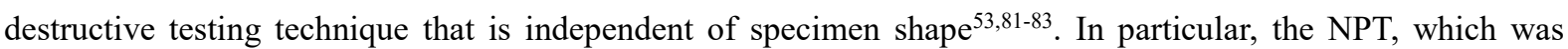
developed by Maruto Testing Machine Company ${ }^{84}$ and is widely used in engineering projects, has been approved as an ISRM suggested method and can be applied to soft rock with UCS $<10 \mathrm{MPa}^{20,83,85-87}$. Previous studies have used the NPT to estimate physico-mechanical properties of soft, low-strength rocks ${ }^{19,20,52,54-56,88}$.

Penetration resistance tests conducted during the present study followed test methods ASTM C403/C403M$16^{89}$ and ASTM C803/C803M-1890, which are used to estimate the in-place strength of concrete or mortar and assess the effects of variables such as water content, using probes or pins. The test apparatus used was a hydraulic digital penetrometer that measures a maximum PRV of $1000 \mathrm{~N}$ and has an accuracy of $\pm 1 \%$ (Fig. 11). The probe is made of shaft-shaped hardened steel and has a diameter of $6.35 \mathrm{~mm}$.

Penetration resistance tests were performed on specimens having the same mixture component ratios and water contents as those of specimens used in the unconfined compression tests. For the tests, the probe was slowly inserted into the specimen until the penetration depth reached $25.4 \mathrm{~mm}$. During this insertion, the maximum value of penetration load was recorded from the digital display, following which the probe was extracted. This process was repeated five times at different sites on each specimen, and the mean value of these readings for each specimen was adopted as the indicative value. Values for some specimens were excluded because fracturing occurred during the penetration procedure, mostly for samples with lower water contents. PRV (in MPa) was calculated as follows:

$$
\mathrm{PRV}=F_{P L} / A_{N}
$$

where $\mathrm{F}_{\mathrm{PL}}$ is the penetration load value $(\mathrm{N}$; i.e., the mean value of the five maximum load values read from five penetration tests on each specimen) and $A_{N}$ is the area $\left(0.317 \mathrm{~cm}^{2}\right)$ of the probe. PRVs of the tested specimens are reported in Table 5 .

\section{Results and discussion}

\section{- Effect of breccia content on the mechanical properties of fault core}

The presence of breccia (or fragments) affects the mechanical properties of a multi-component mixture such as fault core c $^{38,91}$. Here, using experimental results reported in Tables 2 and 4, the relationships between breccia content and UCS, $\mathrm{E}_{\mathrm{s} 50}$, and $\mathrm{E}_{\mathrm{t} 50}$ of the studied artificial fault cores were analyzed.

Effect of breccia content on UCS. UCS values are $0.01-2.79,0.01-1.27$, and $0.02-0.96 \mathrm{MPa}$ for breccia contents of 0,20 , and $40 \mathrm{wt} . \%$, respectively, with UCS tending to decrease as breccia content increases (Table 6, Fig. 12). The mean values of UCS decrease from 0.77 to 0.43 to $0.34 \mathrm{MPa}$ as breccia content increases 
from 0 to 20 to $40 \mathrm{wt} . \%$, respectively (Table 6). This pattern is consistent with the experimental results for fault rocks reported by Medley ${ }^{39}$ and Kahraman and Alber ${ }^{14}$, but differs from those reported by Sonmez et al. ${ }^{44}$, who found increased UCS with increasing breccia content. Kahraman and Alber ${ }^{14}$ explained these different relationships in terms of the relative strengths of breccia and matrix in the fault rocks, with fault breccia (Ankara agglomerate) being stronger than matrix in the samples of Sonmez et al. ${ }^{44}$, and conversely in the samples of Kahraman and Alber ${ }^{14}$, where the fault breccia was composed of shale. However, in the present study the fault breccia is composed of granite and is therefore stronger than the clay-based matrix, meaning that the results shown in Fig. 12 cannot be explained in terms of breccia/matrix strength differentials. Kobayashi et al. ${ }^{92}$ interpreted the observed decrease in strength with increasing fragment content in their artificial specimens composed of gravelly soft rock in terms of a non-uniform stress distribution and local yielding within specimens. Lindquist and Goodman $^{38}$ reported a proportional relationship between breccia content and strength of mélanges when the volumetric proportion of breccia was relatively high. We thus explain the observed decrease in UCS with increasing breccia content in our artificial specimens in terms of the low volumetric proportion of fault breccia and the weak cohesion/bonding between the different components of the unconsolidated fault core materials.

Effect of breccia content on elastic modulus $\left(E_{s 50}\right.$ and $\left.E_{t 50}\right)$. Maximum, minimum, and mean values of $E_{s 50}$ and $E_{t 50}$ with respect to breccia content are given in Table 7. The ranges of $E_{s 50}$ are 0.1-115.3, 0.393.3, and 0.2-142.0 MPa for breccia contents of 0,20 , and $40 \mathrm{wt} . \%$, respectively, and the respective mean values of $\mathrm{E}_{\mathrm{s} 50}$ are $28.6,22.5$, and $28.5 \mathrm{MPa}$. The range and mean value of $\mathrm{E}_{\mathrm{s} 50}$ for breccia contents of 0 and $40 \mathrm{wt} . \%$ are similar in each case, and higher than those for $20 \mathrm{wt} . \%$ (Table 7, Fig. 13a). The range and mean value of $\mathrm{E}_{\mathrm{t} 50}$ with respect to breccia content are the same as those for $\mathrm{E}_{\mathrm{s} 50}$ (Table 7, Fig. 13b). The relationship between $\mathrm{E}$ and breccia content is more complex than that between UCS and breccia content, and is more difficult to explain. For this reason, Kahraman and Alber ${ }^{14}$ argued that more investigations and data are needed to clarify the relationship between breccia content and $\mathrm{E}$.

\section{- Effect of water content on the mechanical properties of fault core}

The effect of water content on the mechanical properties of the artificial fault core was examined by performing correlation analysis between water content and UCS, $\mathrm{E}_{\mathrm{s} 50}$, and $\mathrm{E}_{\mathrm{t} 50}$ while holding breccia content constant. Increasing water content is known to reduce material strength ${ }^{21,48,49,53,93}$. For example, Avşar et al. ${ }^{20}$ identified a decrease in UCS with increasing water content for water contents of $>11 \%$ in weakly bonded volcanic soils. This pattern was explained by a reduction in the degree of interlocking between grains caused by higher proportions of water, but only above a threshold water content (11\%). Here, UCS of the artificial specimens shows a decrease starting from water contents of $0 \Delta \%$ (Fig. 14), with marked reductions in UCS occurring between water contents of $0 \Delta \%$ and $5 \Delta \%$. In addition, for similar water content, specimens with high breccia contents have lower UCS values. Although data are scattered for a water content of $0 \Delta \%$ and for a breccia content of $0 \mathrm{wt} . \%$, regression models show that UCS is exponentially related to water content for each breccia content of 0,20 , and $40 \mathrm{wt} . \%$, with coefficients of determination $\left(\mathrm{R}^{2}\right)$ of $0.74,0.73$, and 0.75 , respectively (Fig. 14). These are high correlations 
considering the heterogeneity and anisotropy of the fault cores. The relationship between water content and UCS, expressed as an exponential function, is similar to that found previously for soft rocks ${ }^{21,94,95}$. In addition, Erguler and Ulusay ${ }^{53}$ and Hawkins ${ }^{93}$ reported that the main reduction in strength in stronger rocks occurs between water contents of $0 \%$ and $2 \%$.

The relationships between $\mathrm{E}_{\mathrm{s} 50}$ or $\mathrm{E}_{\mathrm{t} 50}$ and breccia content (section 4.2) are unclear. However, these two measures of $\mathrm{E}$ are inversely related to water content (Fig. 15), similar to UCS. $\mathrm{R}^{2}$ values for $\mathrm{E}_{\mathrm{s} 50}$ and water content are $0.68,0.76$, and 0.66 for breccia contents of 0,20 , and $40 \mathrm{wt} . \%$, respectively (Fig. 15a), and for $\mathrm{E}_{\mathrm{t} 50}$ and water content are $0.78,0.82$, and 0.71 for these breccia contents, respectively (Fig. 15b), with both showing the highest correlation at a breccia content of $20 \%$.

In summary, both UCS and E of the artificial fault cores decrease with increasing water content, and these mechanical properties show high correlations with water content for each value of breccia content. The equations describing the relationships between parameters calculated from regression analysis are reported in Table 8 .

\section{- Correlations between mechanical properties}

Estimation of UCS using PRV. PRV might be a useful parameter for estimating the UCS of natural fault cores using a portable penetrometer in the field, given that such materials are difficult to sample and prepare for unconfined compression testing. Generally, a positive correlation exists between PRV and UCS ${ }^{20,96}$. Correlations between PRV and UCS of the artificial fault cores studied here are shown in Fig. 16. Erguler and Ulusay $^{53}$ found that in the case of low-strength $(<5 \mathrm{MPa})$ clay-bearing rock, correlation between needle penetration resistance and UCS is uncertain, and therefore UCS is difficult to predict. However, we found that PRV and UCS ( $<3 \mathrm{MPa})$ in the studied artificial specimens are proportional to each other and have a different relationship for each of the three levels of breccia content (Fig. 16). In addition, for a given UCS, PRV increases with breccia content, which indicates that although PRV and UCS show a moderately strong relationship, the nature of the relationship varies with the constituent components of the material. Therefore, to determine the UCS using PRV it is necessary to consider additional variables such as the breccia content, as done here, rather than taking a simplistic approach.

Relationship between elastic modulus $\left(E_{t 50}\right.$ and $\left.E_{s 50}\right)$ and UCS. Figure 17 shows the

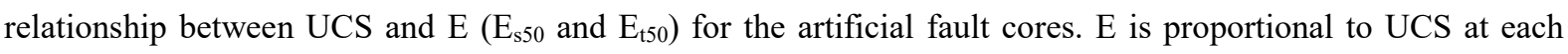
breccia content. $\mathrm{R}^{2}$ values for $\mathrm{E}_{\mathrm{s} 50}$ and UCS are $0.88,0.62$, and 0.82 for breccia contents of 0,20 , and $40 \mathrm{wt} \%$, respectively (Fig. 17a), and for $\mathrm{E}_{\mathrm{t} 50}$ and UCS are $0.88,0.71$, and 0.75 , respectively (Fig. 17b), with both showing the lowest correlation at a breccia content of $20 \mathrm{wt} . \%$. In addition, the slopes of the best-fit regression lines increase as breccia content increases. That is, for similar UCS, specimens with higher breccia contents have higher $\mathrm{E}$, suggesting that low strain results from the presence of breccia. These results indicate that the $\mathrm{E}$ value of fault core is proportional to the strength of the component itself, unlike the UCS, which is analyzed in terms of the bonding between constituent components. 
Correlations between UCS and E have been previously reported in experiments involving soft rocks and sandcement mixtures ${ }^{48,97-101}$. Galván ${ }^{49}$ analyzed data collated from numerous studies and on that basis plotted the relationship (ratio) between UCS and $\mathrm{E}_{50}$ (Fig. 18). The $\mathrm{E}_{50} / \mathrm{UCS}$ ratio was originally proposed by Deere $\mathrm{e}^{102}$ and has since been used for basic descriptions of rock mechanical properties ${ }^{21}$. Figure 18 show that most of results are consistent with the properties of natural rocks. The artificial fault cores have lower UCS and E than sand-cement mixtures. In particular, the data of fault cores and sand-cement mixtures have similar slopes in the figure. These results indicate that the characteristics of the two artificially made specimens are similar to each other and that the clay materials have lower mechanical properties than sand.

\section{Conclusions}

In this study, unconfined compression tests and penetration resistance tests were conducted on 132 artificial specimens to determine the mechanical properties of fault core. The specimens were manufactured by mixing breccia, sand, clay, and water, which are typical components of natural fault cores, to yield mixtures with 11 different constituent component ratios and differing water contents. The measured experimental data allowed the effects of breccia content and water content on mechanical properties (UCS, $\mathrm{E}_{\mathrm{s} 50}$, and $\mathrm{E}_{\mathrm{5} 50}$ ) to be determined and relationships between mechanical properties to be established. Our main conclusions are as follows.

1. UCS of the artificial fault core decreases with increasing breccia content from 0 to 20 to $40 \mathrm{wt} . \%$, but elastic modulus $\left(\mathrm{E}_{\mathrm{s} 50}\right.$ and $\left.\mathrm{E}_{\mathrm{t} 50}\right)$ decreases from breccia contents of 0 to $20 \mathrm{wt} . \%$ and then increases to a breccia content of $40 \mathrm{wt} . \%$.

2. UCS decreases as water content increases, and the reduction is most marked between water contents of $0 \%$ and 5\%. Specimens with high breccia content but similar water content have lower UCS values than do those with low breccia content. Elastic modulus $\left(\mathrm{E}_{\mathrm{s} 50}\right.$ and $\left.\mathrm{E}_{\mathrm{t} 50}\right)$ also decreases with increasing water content. UCS, $\mathrm{E}_{\mathrm{s} 50}$, and $\mathrm{E}_{\mathrm{t} 50}$ of the fault core are exponentially related to water content, and the relationship varies with breccia content.

3. Penetration resistance value (PRV) is proportional to UCS and shows different relationships and correlation strengths depending on breccia content. For a given UCS, PRV increases as breccia content increases, revealing that the nature of the relationship varies with the constituent components of the fault core.

4. Elastic modulus is proportional to UCS, and specimens with higher breccia contents have higher $\mathrm{E}_{\mathrm{s} 50}$ and $\mathrm{E}_{\mathrm{t} 50}$ for similar UCS. The UCS and E of the studied artificial fault cores are consistent with those of soft rock and sand-cement mixtures. In addition, the measured $\mathrm{E}_{50} / \mathrm{UCS}$ ratio shows a similar slope to that of sand-cement mixtures, although with lower values.

5. Breccia content, water content, and PRV values can be obtained through relatively simple specimen preparation and testing procedures. The results of this study should be of use for estimating the mechanical properties of fault core, which is typically highly challenging with regard to field sampling and specimen preparation for laboratory testing. 


\section{Data availability}

The data that support the findings of this study are available from the corresponding author upon reasonable request.

\section{References}

1. Caine, J. S., Evans, J. P. \& Forster, C. B. Fault zone architecture and permeability structure. Geology. 24, 1025-1028 (1996)

2. Heynekamp, M. R., Goodwin, L. B., Mozley, P. S. \& Haneberg, W. C. Controls on fault-zone architecture in poorly lithified sediments, Rio Grande Rift, New Mexico: implications for fault zone permeability and fluid flow. In Faults and Subsurface Fluid Flow in the Shallow Crust. Geophysical Monograph Series (eds. Haneberg, W. C., Mozley, P. S., Moore, J. C. \& Goodwin, L. B.) 113, 27-49 (American Geophysical Union, 1999).

3. Faulkner, D. R., Lewis, A. C. \& Rutter, E. H. On the internal structure and mechanics of large strike-slip fault zones: field observations of the Carboneras fault in southeastern Spain. Tectonophysics. 367, 235251 (2003).

4. Shipton, Z. K. \& Cowie, P. A. A conceptual model for the origin of fault damage zone structures in highporosity sandstone. J. Struct. Geol. 25, 333-344 (2003).

5. Crider, J. G. \& Peacock, D. C. P. Initiation of brittle faults in the upper crust: a review of field observations. J. Struct. Geol. 26, 691-707 (2004).

6. Shipton, Z. K., Soden, A. M., Kirkpatrick, J. D., Bright, A. M. \& Lunn, R. J. How thick is a fault? Fault displacement-thickness scaling revisited. In Earthquakes: Radiated Energy and the Physics of Faulting. Geophysical Monograph Series (eds. Abercrombie, R., McGarr, A., Toro, G. \& Kanamori, H.) 170, 193 198 (American Geophysical Union, 2006).

7. de Joussineau, G. \& Aydin, A. The evolution of the damage zone with fault growth in sandstone and its multiscale characteristics. J. Geophys. Res. 112, B12401 (2007).

8. Wibberley, C. A. J., Yielding, G. \& Di, Toro G. D. Recent advances in the understanding of fault zone internal structure: a review. In The Internal Structure of Fault Zones: Implications for Mechanical and Fluid-Flow Properties. Special Publication (eds. Wibberley, C. A. J. et al.) 299, 5-33 (The Geological Society of London, 2008).

9. Faulkner, D. R. et al. A review of recent developments concerning the structure, mechanics and fluid flow properties of fault zones. J. Struct. Geol. 32, 1557-1575 (2010).

10. Gudmundsson, A., Simmenes, T. H., Belinda, L. \& Philipp, S. L. Effects of internal structure and local stresses on fracture propagation, deflection, and arrest in fault zones. J. Struct. Geol. 32, 1643-1655 (2010).

11. Gudmundsson, A. Rock Fractures in Ggeological Processes. p299 (Cambridge University Press, 2011).

12. Bieniawski, Z. T. Classification of rock masses for engineering: The RMR system and future trend. In Comprehensive Rock Engineering (ed. Hudson, J.A.) 3, 553-573 (Pergamon Press, 1993).

13. Riedmüller, G., Brosch, F. J., Klima, K. \& Medley, E. W. Engineering geological characterization of brittle faults and classification of fault rocks. Felsbau 19, 13-19 (2001).

14. Kahraman, S. \& Alber, M. Estimating unconfined compressive strength and elastic modulus of a fault 
breccia mixture of weak blocks and strong matrix. Int. J. Rock Mech. Min. Sci. 43, 1277-1287 (2006).

15. Stille, H., \& Palmström, A. Ground behaviour and rock mass composition in underground excavations. Tunn. Undergr. Sp. Tech. 23, 46-64 (2008).

16. Alber, M. \& Kahraman, S. Predicting the uniaxial compressive strength and elastic modulus of a fault breccia from texture coefficient. Rock Mech. Rock Eng. 42, 117-127 (2009).

17. Kahraman, S., Alber, M., Fener, M. \& Gunaydin, O. Evaluating the geomechanical properties of Misis fault breccia (Turkey). Int. J. Rock. Mech. Min. Sci. 43, 1469-1479 (2008).

18. Habimana, J., Labiouse, V. \& Descoeudres, F. Geomechanical characterisation of cataclastic rocks: experience from the Cleuson-Dixence project. Int. J. Rock. Mech. Min. Sci. 39, 677-693 (2002).

19. Aydan, Ö., Sato, A. \& Yagi, M. The inference of geo-mechanical properties of soft rocks and their degradation from needle penetration tests. Rock. Mech. Rock. Eng. 47, 1867-1890 (2014).

20. Avşar, E., Ulusay, R. \& Aydan, Ö. On the difficulties of geotechnical sampling and practical estimates of the strength of a weakly bonded volcanic soil. Bull. Eng. Geol. Environ. 74, 1375-1394 (2015).

21. Kanji, M. A. Critical issues in soft rocks. Journal of Rock Mechanics and Geotechnical Engineering 6, 186-195 (2014).

22. Sausgruber, T. \& Brandner, R. The relevance of brittle fault zones in tunnel construction-Lower inn valley feeder line north of the Brenner Base tunnel, Tyrol, Austria. Mitt. Österr. Geol. Ges. 94, 157-172 (2003).

23. Morrow, C. A., Moore, D. E. \& Lockner, D. A. The effect of mineral bond strength and adsorbed water on fault gouge frictional strength. Geophys. Res. Lett. 27, 815-818(2000).

24. Saffer, D. M. \& Marone, C. Comparison of smectite- and illite-rich gouge frictional properties: Application to the updip limit of the seismogenic zone along subduction megathrusts. Earth. Planet. Sci. Lett. 215, 219- 235 (2003).

25. Kopf, A. \& Brown, K. M, Friction experiments on saturated sediments and their implications for the stress state of the Nankai and Barbados subduction thrusts. Mar. Geol. 202, 193-210(2003).

26. Boettcher, M. S. \& Marone, C. Effects of normal stress variation on the strength and stability of creeping faults. J. Geophys. Res. 109, B03406 (2004).

27. Moore, D. E. \& Lockner, D. A. Crystallographic controls on the frictional behavior of dry and watersaturated sheet structure minerals. J. Geophys. Res. 109, B03401 (2004).

28. Bourlange, S., Jouniaux, L. \& Henry, P. Data report: Permeability, compressibility, and friction coefficient measurements under confining pressure and strain, Leg 190, Nankai Trough. In Proceedings of the Ocean Drilling Program, Scientific results (eds. Mikada, H. et al.) 190/196, 1-16 (2006).

29. Tesei, T., Collettini, C., Carpenter, B. M., Viti, C. \& Marone, C. Frictional strength and healing behavior of phyllosilicate-rich faults. J. Geophys. Res. 117, B09402 (2012).

30. Ikari, M. J., Saffer, D. M. \& Marone, C. Effect of hydration state on the frictional properties of montmorillonite-based fault gouge. J. Geophys. Res. 112, B06423 (2007).

31. Ikari, M. J., Saffer, D. M. \& Marone, C. Frictional and hydrologic properties of clay-rich fault gouge. J. Geophys. Res. 114, B05409 (2009).

32. Haines, S. H., Kaproth, B., Marone, C., Saffer, D. \& der Pluijm, B. V. Shear zones in clay-rich fault gouge: A laboratory study of fabric development and evolution. J. Struct. Geol. 51, 206-225 (2013).

33. Henderson, I. H. C., Ganerod, G. V., \& Braathen, A. The relationship between particle characteristics and frictional strength in basal fault breccias: Implications for fault-rock evolution and rockslide susceptibility. Tectonophysics 486, 132-149 (2010). 
34. Moon, S. W. et al. Correlation analysis between weight ratio and shear strength of fault materials using multiple regression analysis. The Journal of Engineering Geology 24, 397-409 (2014) (in Korean with English abstract).

35. Yun, H. S., Moon, S. W. \& Seo, Y. S Setting of the range for shear strength of fault cores in Gyeongju and Ulsan using regression analysis. J. of Korean Tunn Undergr Sp. Assoc. 17, 127-140 (2015) (in Korean with English abstract).

36. Kim, K. Y., Suh, H. S., Yun, T. S., Moon, S. W. \& Seo, Y. S. Effect of particle shape on the shear strength of fault gouge. Geosci. J. 20, 351-359 (2016).

37. Yun, H. S., Moon, S. W. \& Seo, Y. S. Relationship between Shear Strength and Component Content of Fault Cores. Econ. Environ. Geol. 52, $65-79$ (2019) (in Korean with English abstract).

38. Lindquist, E. S. \& Goodman, R. E The strength and deformation properties of the physical model melange. In Proceedings of the 1st North American Rock Mechanics Symposium (NARMS), Austin, Texas, Rotterdam (eds. Nelson, P. P. \& Laubach, S. E.) (AA Balkema, 1994).

39. Medley, E. W. The engineering characterization of melanges and similar block-in-matrix rocks (bimrocks). PhD thesis, University of California, Berkeley (1994).

40. Buergi, C., Parriaux, A., Franciosi, G. \& Rey, J-Ph. Cataclastic rocks in underground structures Terminology and impact on the feasibility of projects (initial results). Eng. Geol. 51, 225-235 (1999).

41. Laws, S., Eberhardt, E., Loew, S. \& Descoeudres, F. Geomechanical properties of shear zones in the Eastern Aar Massif, Switzerland and their implication on tunnelling. Rock. Mech. Rock. Eng. 36, 271303 (2003).

42. Medley, E. W. Orderly characterization of chaotic Franciscan Melanges. Felsbau, J. of Engineering Geology, Geomechanics and Tunneling. 19, 20-33 (2001).

43. Medley, E. W. Estimating block size distribution of melanges and similar block-in-matrix rocks (bimrocks). In Proceedings of the 5th North American Rock Mechanics Symposium (NARMS), Toronto, Canada (eds. Hammah, R., Bawden, W., Curran, J. \& Telesnicki. M.) 509-516 (University of Toronto Press, 2002).

44. Sonmez, H., Gokceoglu, C., Tuncay, E., Medley, E. W. \& Nefeslioglu, H. A. Relationship between volumetric block proportion and overall UCS of a volcanic bimrock. Felsbau 22, 27-34 (2004a)

45. Sonmez, H., Gokceoglu, C., Medley, E. W., Tuncay, E. \& Nefeslioglu, H. A. Estimating the uniaxial compressive strength of a volcanic bimrock. Int. J. Rock. Mech. Min. Sci. 43, 554-561 (2006).

46. Chang, C., Zoback, M. D. \& Khaksar, A. Empirical relations between rock strength and physical properties in sedimentary rocks. J. Petrol. Sci. Eng. 51, 223-237 (2006).

47. Kanji, M. A. Dam foundation on weak and fractured rocks: problems and solutions. In Proceedings of the 3rd South American Congress on Rock Mechanics, IAEG, Caracas, Venezuela 235-252 (1990) (in Spanish).

48. Kanji, M. A. \& Galván, V. L. Correlation of properties of soft rocks. In Proceedings of the 2nd International Symposium on Hard Soils and Soft Rocks, Naples, Italy 239-244 (1998).

49. Galván, V. Simulation of the geotechnical properties of arenaceous soft rocks by means of artificial materials. PhD Thesis, Escola Politécnica, Universidade de São Paulo, São Paulo (1999) (in Portuguese).

50. Horpibulsuk, S., Miura, N. \& Nagaraj, T. S. Assessment of strength development in cement-admixed high water content clays with Abrams' law as a basis. Technical Note, Géotechnique 53, 439-444 (2003).

51. Consoli, N. C., Rosa, D. A., Cruz, R. C. \& Rosa, A. D. Water content, porosity and cement content as parameters controlling strength of artificially cemented silty soil. Technical Note, Eng. Geol. 122, 328- 
$333(2011)$.

52. Koncagül, E. C. \& Santi, P. M. Predicting the unconfined compressive strength of the Breathitt shale using slake durability, Shore hardness and rock structural properties. Int. J. Rock. Mech. Min. Sci. 36, 139-153 (1999).

53. Erguler, Z. A. \& Ulusay, R. Water-induced variations in mechanical properties of clay-bearing rocks. Int. J. Rock. Mech. Min. Sci. 46, 355-370 (2009).

54. Nagan-Tillard, D. J. M., Verwaal, W., Mulder, A., Engin, H. K. \& Ulusay, R. Application of the needle penetration test to a calcarenite, Maastricht, the Netherlands. Eng. Geol. 123, 214-224 (2011).

55. Aydan, Ö. The inference of physico-mechanical properties of soft rocks and the evaluation of the effect of water content and weathering on their mechanical properties from needle penetration tests. In Proceedings of the 46th U.S. Rock Mechanics/Geomechanics Symposium, ARMA, Chicago, Illinois ARMA-2012-639 (on CD) (2012)

56. Ulusay, R. \& Erguler, Z. A. Needle penetration test: evaluation of its performance and possible uses in predicting strength of weak and soft rocks. Eng. Geol. 149-150, 47-56 (2012).

57. Grima, M. A. \& Babuška, R. Fuzzy model for the prediction of unconfined compressive strength of rock samples. Int. J. Rock. Mech. Min. Sci. 36, 339-49 (1999).

58. Ali, M. \& Chawathé, A. Using artificial intelligence to predict permeability from petrographic data. Comput. Geosci. 26, 915-25 (2006).

59. Finol, J., Guo, Y. K. \& Jing, X. D. A rule based fuzzy model for the prediction of petrophysical rock parameters. J. Petr. Sci. Eng. 29, 97-113 (2001).

60. Kayabasi, A., Gokceoglu, C. \& Ercanoglu, M. Estimation the deformation modulus of rock masses: a comparative study. Int. J. Rock. Mech. Min. Sci. 40, 55-63(2003).

61. Gokceoglu, C. \& Zorlu, K. A fuzzy model to predict the uniaxial compressive strength and the modulus of elasticity of a problematic rock. Eng. Appl. Artif. Intell. 17, 61-72 (2004).

62. Sonmez, H., Tuncay, E. \& Gokceoglu, C. Models to predict the uniaxial compressive strength and the modulus of elasticity for Ankara Agglomerate. Int. J. Rock. Mech. Min. Sci. 41, 717-729 (2004b).

63. Kahraman, S., Gunaydin, O., Alber, M. \& Fener, M. Evaluating the strength and deformability properties of Misis fault breccia using artificial neural networks. Expert Syst. Appl. 36, 6874-6878 (2009).

64. Galván, V. \& Kanji, M. A. Simulation of arenaceous weak rocks by means of cemented sands. In Proceedings of the 12th International Congress of International Society for Rock Mechanics, Beijing, China 751-752 (2011).

65. Yoon, S. H. \& Chough, S. K. Regional strike slip in the eastern continental margin of Korea and its tectonic implications for the evolution of Ulleung Basin, East Sea (Sea of Japan). Geol. Soc. Am. Bull. 107, 83-97 (1995).

66. Chough, S. K., Kwon, S. T., Ree, J. H. \& Choi, D. K. Tectonic and sedimentary evolution of the Korean peninsula: a review and new view. Earth-Sci. Reviews 52, 175-235 (2000).

67. Spry, A. Metamorphic Textures (Pergamon, 1969).

68. Higgins, M. W. Cataclastic Rocks. Geological Survey Professional Paper 687 (United States Government Printing Office, 1971).

69. Laznicka, P. Breccias and Coarse Fragmentites: Petrology, Environments, Associations, Ores. Developments in Economic Geology Series 25 (Elsevier, Amsterdam, 1988)

70. Snoke, A. W., Tullis, J. \& Todd, V. R. Fault-Related Rocks: A Photographic Atlas. Princeton Legacy Library (Princeton University Press, 1998). 
71. Clark, C. \& James, P. Hydrothermal brecciation due to fluid pressure fluctuations: examples from the Olary Domain, South Australia. Tectonophysics 366, 187-206 (2003).

72. Koša, E., Hunt, D., Fitchen, W. M., Bockel-Rebelle, M-O. \& Roberts, G. The heterogeneity of palaeocavern systems developed along syndepositional fault zones: The Upper Permian Capitan Platform, Guadalupe Mountains, U.S.A. In Permo-Carboniferous Carbonate Platforms and Reefs. SEPM Special Publication No. 78 and AAPG Memoir (eds. Ahr, W. M., Harris, P. M., Morgan, W. A. \& Somerville, I. D.) 83, 291-322 (2003).

73. Woodcock, N. H. \& Mort, K. Classification of fault breccias and related fault rocks. Geol. Mag. 145, 435-440 (2008).

74. American Society for Testing and Materials (ASTM) D2487-17 Standard practice for classification of soils for engineering purposes (unified soil classification system) (2017).

75. American Society for Testing and Materials (ASTM) D422-63 Standard test method for particle-size analysis of soils (2007).

76. American Society for Testing and Materials (ASTM) D1140-17 Standard test methods for determining the amount of material finer than $75-\mu \mathrm{m}$ (No. 200) sieve in soils by washing (2017).

77. American Society for Testing and Materials (ASTM) D2166-16 Standard test method for unconfined compressive strength of cohesive soil (2016).

78. American Society for Testing and Materials (ASTM) D2216-10 Standard test method for laboratory determination of water (moisture) content of soil and rock by mass (2010).

79. International Society for Rock Mechanics and Rock Engineering (ISRM) ISRM suggested methods: rock characterization, testing and monitoring (ed. Brown, E.T.) (Pergamon Press, 1981).

80. Deer, D. U. \& Miller, R. P. Engineering classification and index properties for intact rock. Technical report No. AFWL-TR-65-116, Air Force Weapon Laboratory, New Mexico 90-99 (1966).

81. Okada, S., Izumiya, Y., Iizuka, Y. \& Horiuchi, S. The estimation of soft rock strength around a tunnel by needle penetration test. J. Jpn. Soc. Soil Mech. Found. Eng. 33, 35-38 (1985) (in Japanese).

82. Yamaguchi, Y. et al. Verification of design strength of soft rock foundation for dams by needle penetration test. Journal of Japanese Society for Engineering Geology 46, 20-27 (2005) (in Japanese).

83. Ulusay, R. et al. ISRM suggested method for the needle penetration test. Rock. Mech. Rock. Eng. 47, 1073-1085 (2014).

84. MARUTO Testing Machine Company Instructions for SH-70 penetrometer (NANGAN-PENETOROKEI) (1999) (in Japanese).

85. Japan Society of Civil Engineers (JSCE) A suggested method for investigation and testing of soft rocks. Committee on rock mechanics of JSCE (1991) (in Japanese).

86. Japanese Geotechnical Society (JGS) Method for needle penetration test (JGS: 3431-2012). Japanese standards and explanations of geotechnical and geoenvironmental investigation methods, 1, 426-432 (JGS Publication, 2012) (in Japanese).

87. International Society for Rock Mechanics and Rock Engineering (ISRM) The ISRM suggested methods for rock characterization, testing and monitoring: 2007-2014 (ed. Ulusay, R.) (Springer, 2014).

88. Aydan, Ö., Seiki, T., Ito, T., Ulusay, R. \& Yüzer, E. A comparative study on engineering properties of tuffs from Cappadocia of Turkey and Oya of Japan. In Proceedings of the Symposium on Modern Applications of Engineering Geology, Turkish National Group of Engineering, Denizli, Turkey 425-433 (2006).

89. American Society for Testing and Materials (ASTM) C403/C403M-16 Standard test for time of setting 
of concrete mixtures by penetration resistance (2016).

90. American Society for Testing and Materials (ASTM) C803/C803M-18 Standard test method for penetration resistance of hardened concrete (2017)

91. Yoshinaka, R., Osada, M., Saotome, A. \& Sugiyama, H. Strength and deformation characteristics of undisturbed volcanic breccia. Journal of Geotechnical Engineering, 673(III-54), 85-100 (2001) (in Japanese).

92. Kobayashi, T., Yoshinaka, R. \& Mimuro, T. Mechanical properties and failure mechanism of gravelly soft rocks. In Rock Foundation: Proceedings of the International Workshop on Rock Foundation, Tokyo, Japan 91-98 (Balkema, 1995).

93. Hawkins, A. B. Aspects of rock strength. Bull. Eng. Geol. Environ. 57, 17-30 (1998).

94. Lashkaripour, G. R. Predicting mechanical properties of mudrock from index parameters. Bull. Eng. Geol. Environ. 61, 73-77 (2002).

95. Chen, H. \& Hu, Z. Y. Some factors affecting the uniaxial strength of weak sandstones. Bull. Eng. Geol. Environ. 62, 323-332 (2004).

96. Maruto Corporation Penetrometer for Soft Rock: Model SH-70 Instruction Manual (2006) (in Japanese).

97. Lama, R. D. \& Vutukuri, V. S. Handbook on Mechanical Properties of Rocks. II (Trans Tech Publications, 1978).

98. Carmichael, R. S. Handbook of Physical Properties of Rocks. II (CRC Press, 1982).

99. Jizba, D. Mechanical and acoustical properties of sandstones and shales. PhD thesis, Stanford University (1991).

100.Wong, T-F., David, C. \& Zhu W The transition from brittle faulting to cataclastic flow in porous sandstones: mechanical deformation. J. Geophys. Res. 102, 3009-3025 (1997).

101.Bradford, I. D. R., Fuller, J., Thompson, P. J. \& Walsgrove, T. R. Benefits of assessing the solids production risk in a North Sea reservoir using elastoplastic modeling. In SPE/ISRM Rock Mechanics in Petroleum Engineering, Trondheim, Norway 261-269(1998).

102.Deere, D. U. Geologic considerations. In Rock Mechanics in Engineering Practice (eds. Stagg, K. G., Zienkiewicz, O.) (John Wiley and Sons, 1968).

\section{Acknowledgements}

This research was supported by Basic Science Research Program through the National Research Foundation of Korea (NRF) funded by the Ministry of Education (No. 2019R1I1A1A0106303).

\section{Author contributions}

H.-S. Y. and Y.-S.S. designed the experiments. H.-S. Y. and S.-W.M. conducted the experiments and data processing. H.-S. Y. analyzed data and wrote main manuscript. All authors reviewed and edited the manuscript.

\section{Competing interests}

The authors declare no competing interests. 

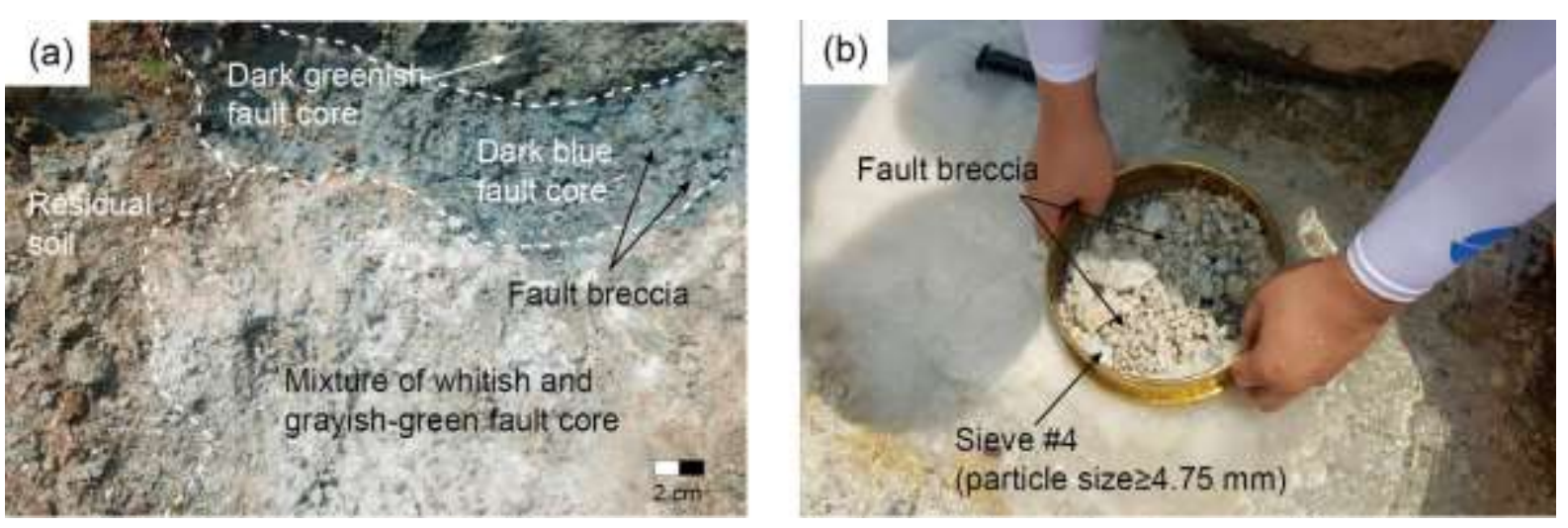

Figure 1. (a) Outcrop photograph of fault core sampled from the Ocheon Fault Zone for the manufacture of artificial specimens. (b) Breccia from the fault core zone classified using sieve $\# 4$ ( $\geq 4.75 \mathrm{~mm})$.

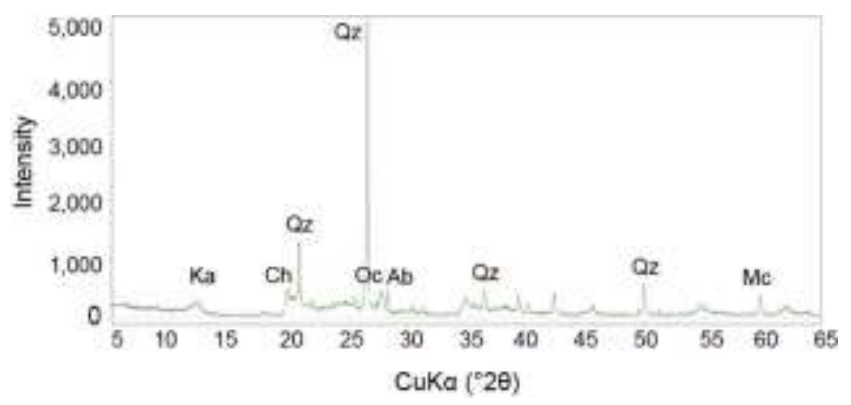

Figure 2. Results of XRD analysis of the clay material used in the manufacture of artificial specimens. Mineral abbreviations: albite $(\mathrm{Ab})$, chlorite $(\mathrm{Ch})$, kaolinite $(\mathrm{Ka})$, microcline $(\mathrm{Mc})$, orthoclase $(\mathrm{Oc})$, and quartz $(\mathrm{Qz})$.

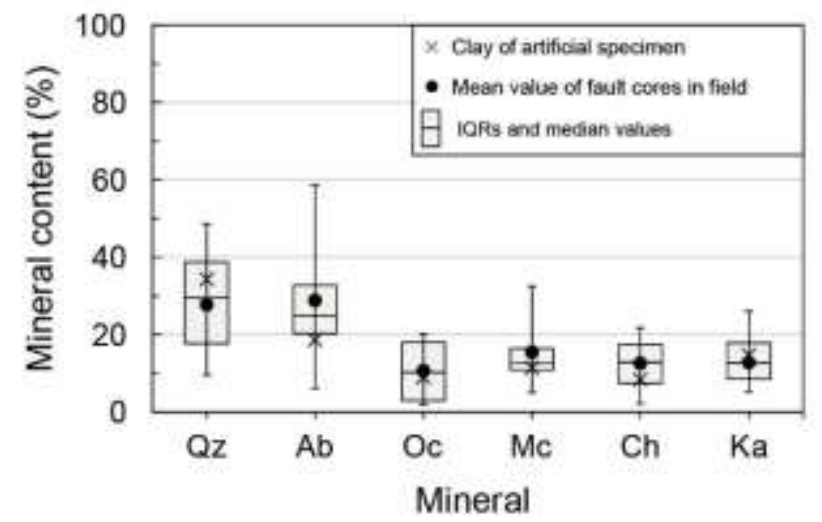

Figure 3. Box plots showing the mineral contents of 40 fault-core-zone clays sampled from the field and mineral contents of the clay material used for artificial specimen manufacture superimposed on the box plots. The boxes are inter-quartile ranges (IQRs). Mineral abbreviations: albite (Ab), chlorite $(\mathrm{Ch})$, kaolinite $(\mathrm{Ka})$, microcline $(\mathrm{Mc})$, orthoclase (Oc), and quartz (Qz). 

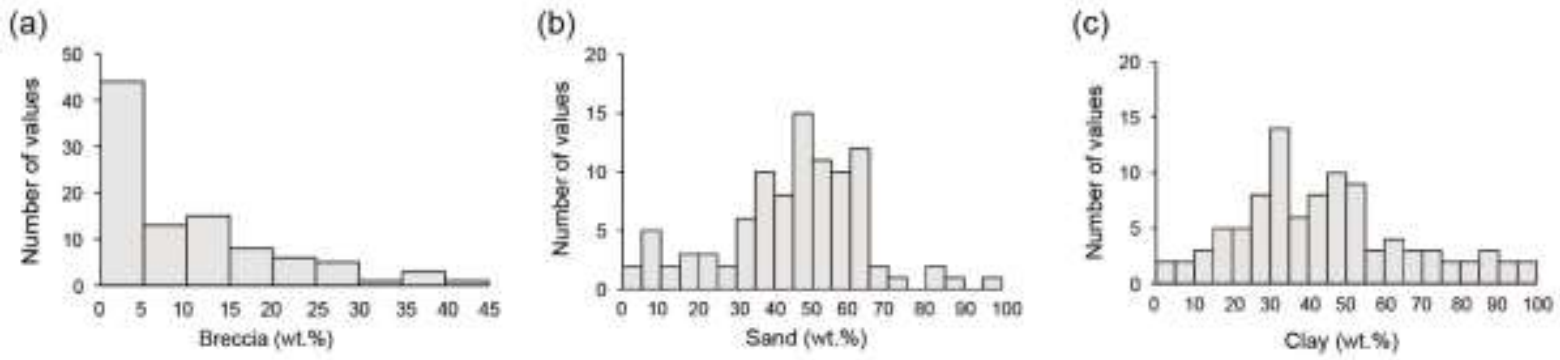

Figure 4. Histograms of (a) breccia, (b) sand, and (c) clay components in 96 natural fault cores obtained from the several fault zones in South Korea. These particle-size data were used to determine the mixing ratios of constituent components in the artificial specimens.
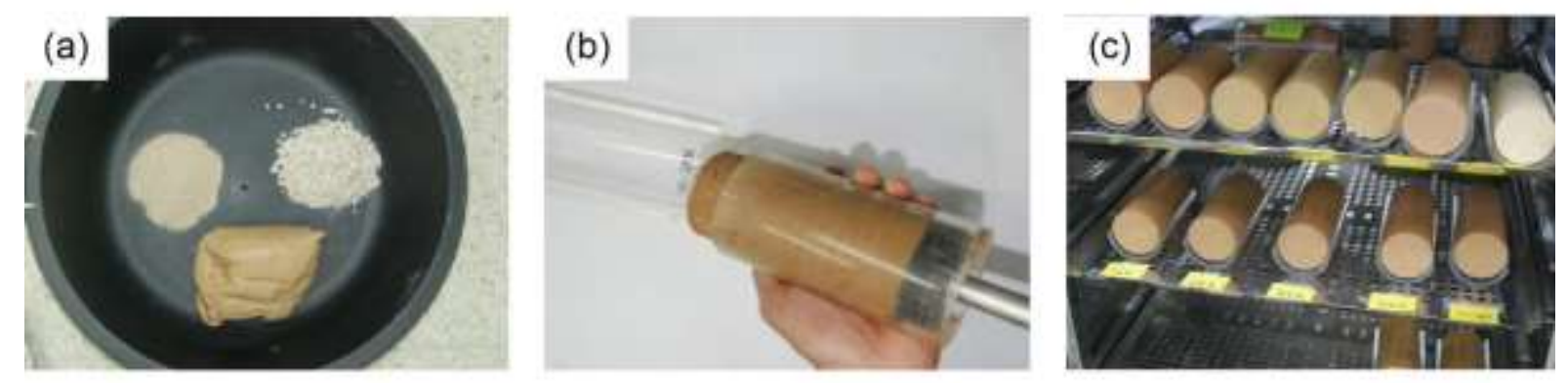

Figure 5. Photographs showing the preparation procedure for artificial specimens. (a) Constituent components (breccia, sand, and clay) ready for mixing. These materials were mixed with water according to the mixing ratios given in Table 2. (b) Cylindrical specimens formed using acrylic tubes. (c) Artificial specimens being dried at $40{ }^{\circ} \mathrm{C}$ for various durations $(0,12,24,36,48$, or $72 \mathrm{~h})$ to produce specimens with different water contents.

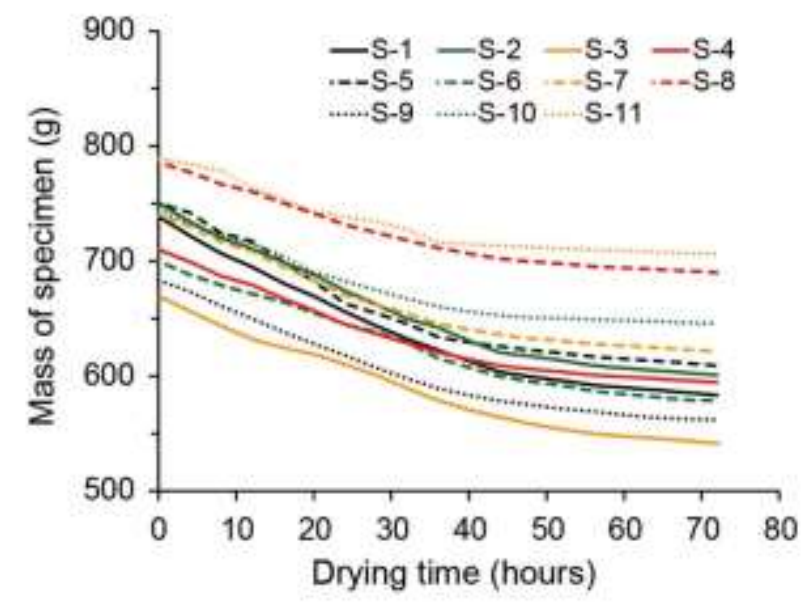

Figure 6. Change in mass with drying time of specimens dried for $72 \mathrm{~h}$. Very little change in mass is observed after $65 \mathrm{~h}$. 


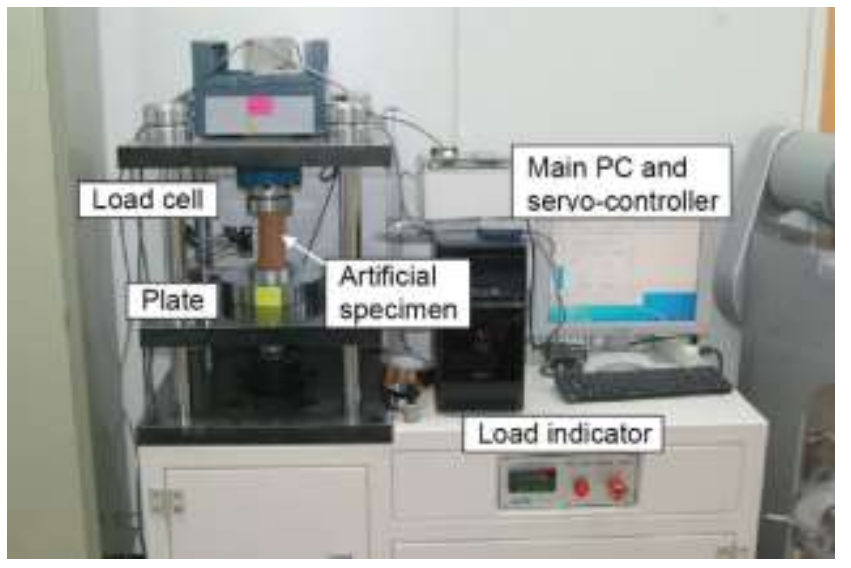

Figure 7. Experimental setup for unconfined compression tests.
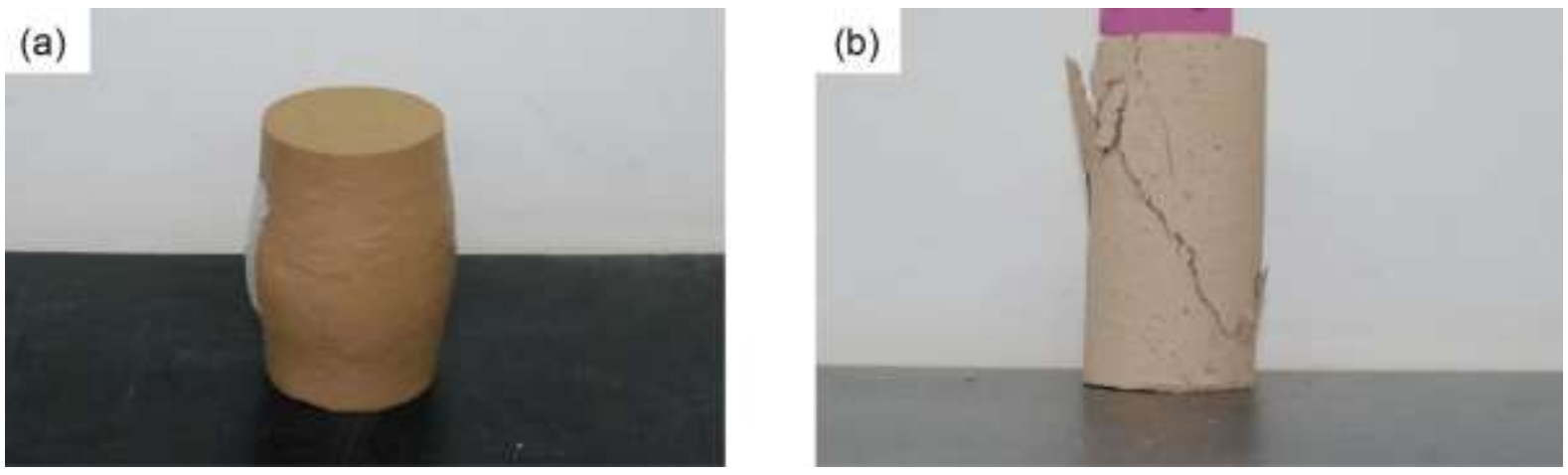

Figure 8. Photographs of (a) S-2a and (b) S-11d after unconfined compression tests. S-2a was deformed plastically, without any failure plane, whereas $\mathrm{S}-11 \mathrm{~d}$ shows a failure mode typical of rock.
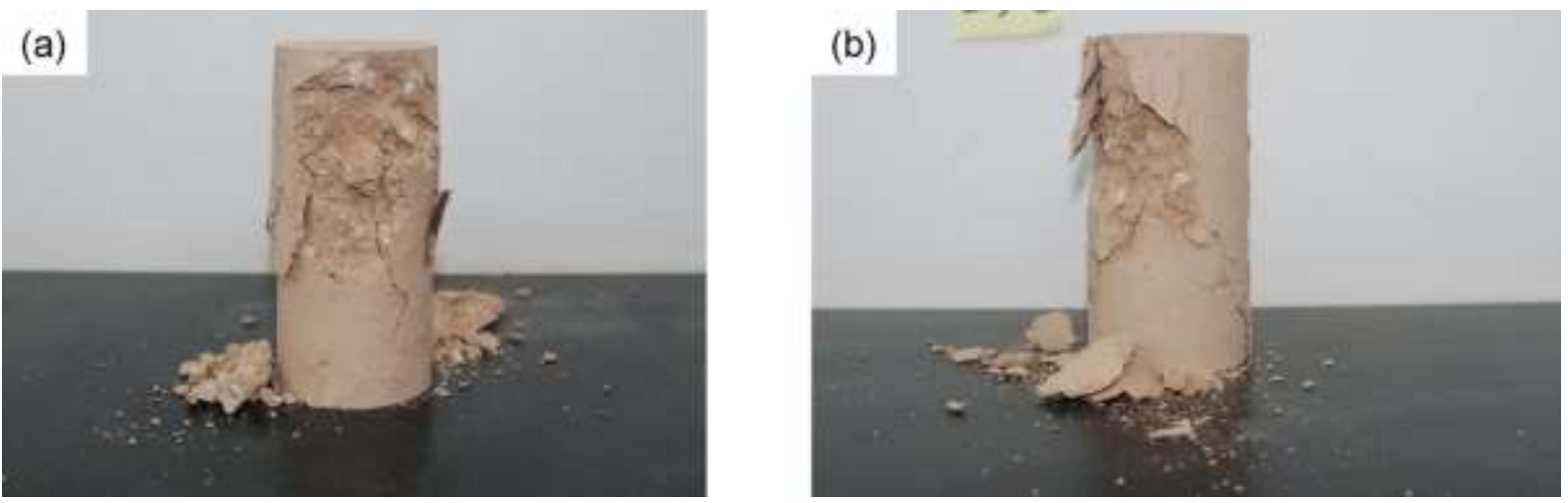

Figure 9. Photographs of failure planes in (a) S-6E and (b) S-7d passing around breccia after unconfined compression tests. 


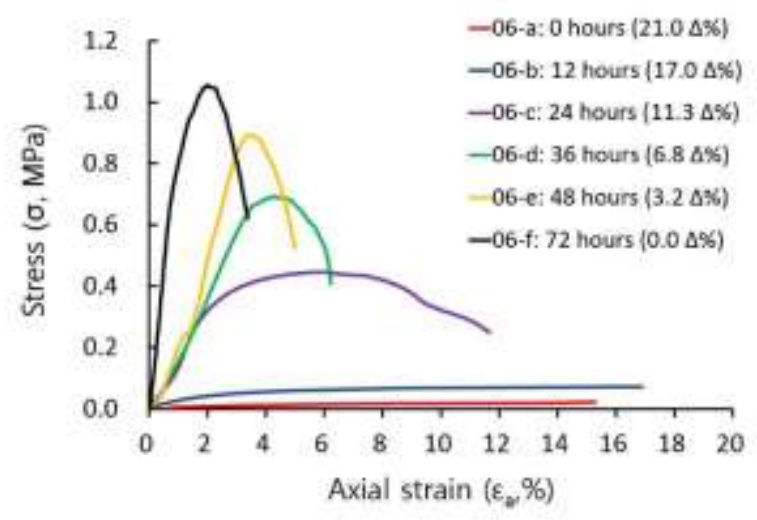

Figure 10. Stress-strain curves from unconfined compression tests performed on specimen set S-6. The numbers in parentheses indicate the water content for each sample after a given drying time.

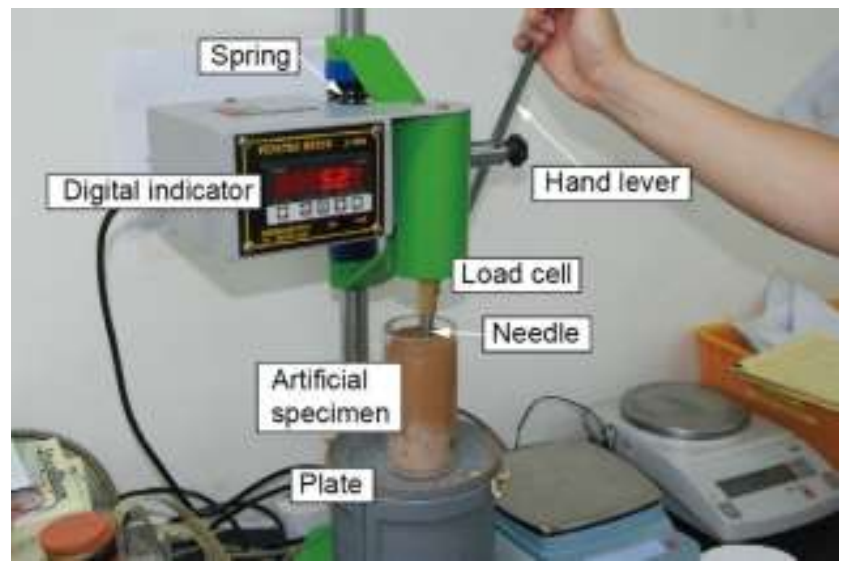

Figure 11. Penetrometer with digital output used for penetration resistance tests.

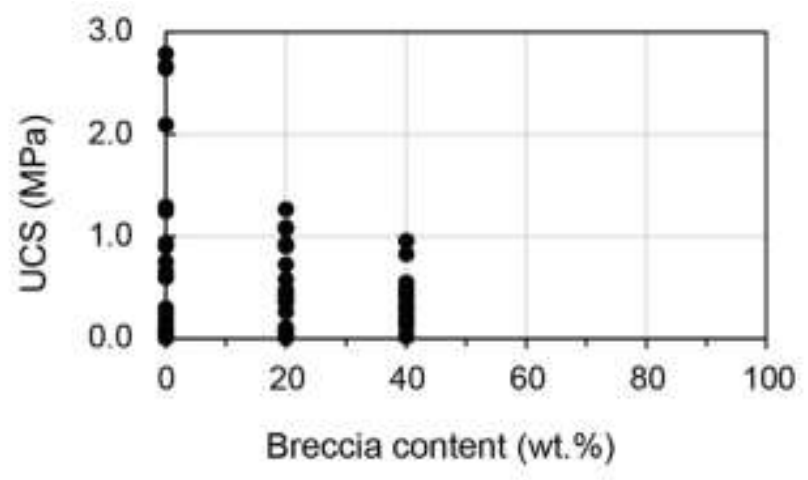

Figure 12. Effect of breccia content on the unconfined compressive strength (UCS) of artificial fault core. 
(a)

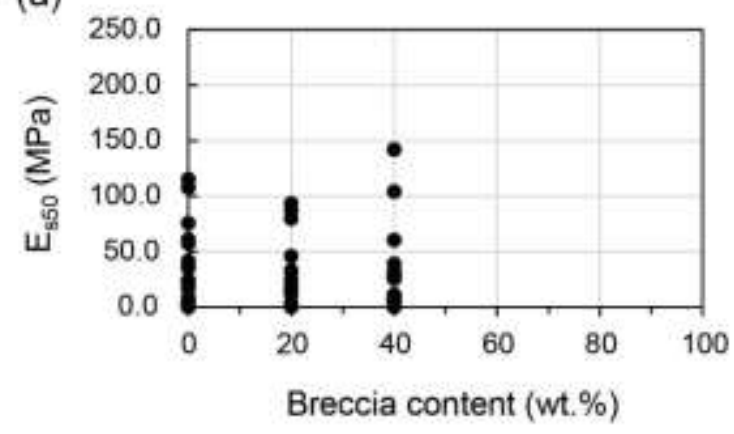

(b)

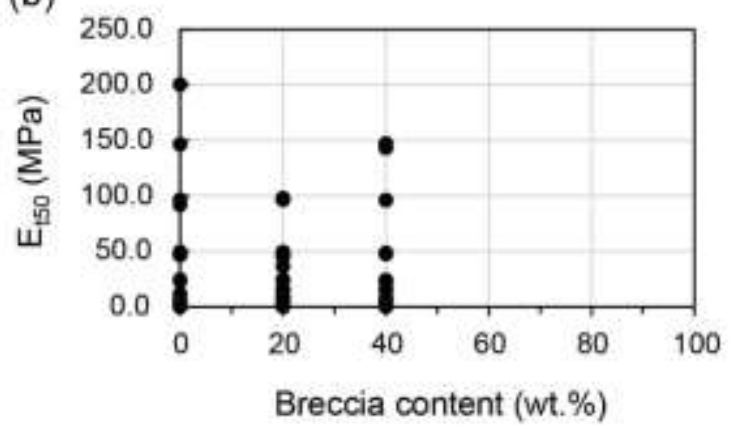

Figure 13. Effect of breccia content on (a) the secant modulus at $50 \%$ ultimate strength $\left(\mathrm{E}_{\mathrm{s} 50}\right)$ and $(\mathbf{b})$ the tangent modulus at $50 \%$ ultimate strength $\left(\mathrm{E}_{\mathrm{t} 50}\right)$ of artificial fault-core-zone materials.

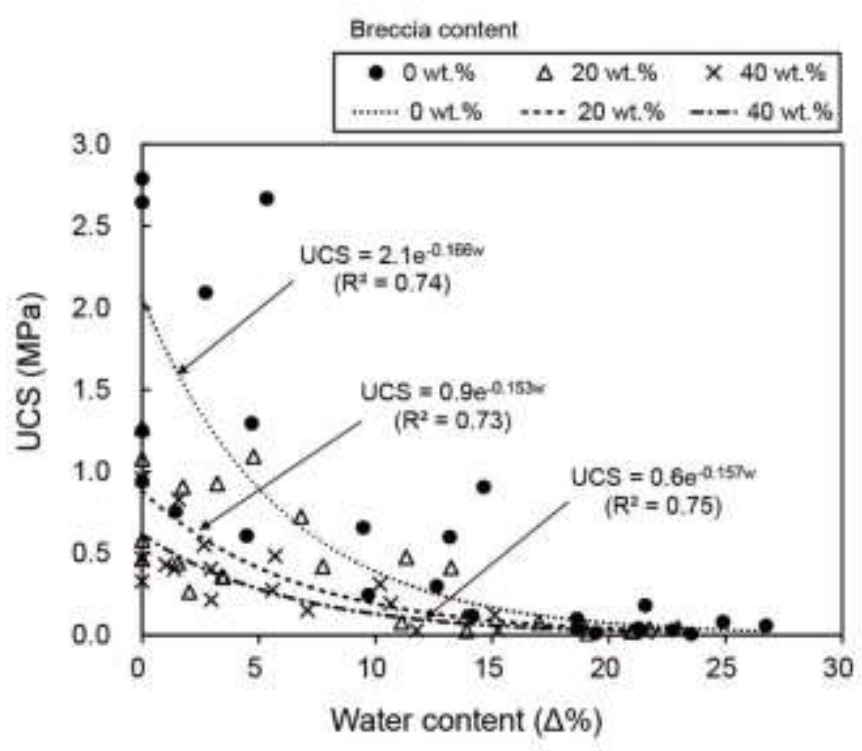

Figure 14. Relationship between unconfined compressive strength (UCS) and water content with respect to three breccia contents $(0,20$, and $40 \mathrm{wt} . \%)$. 
(a)

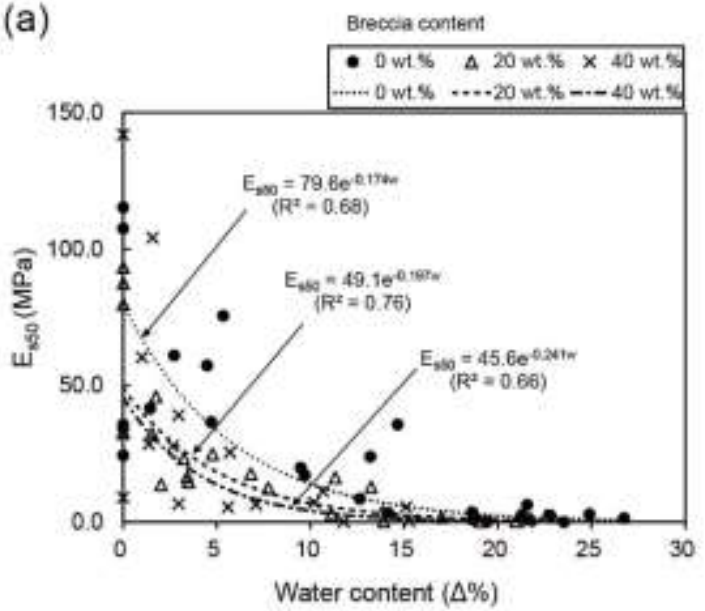

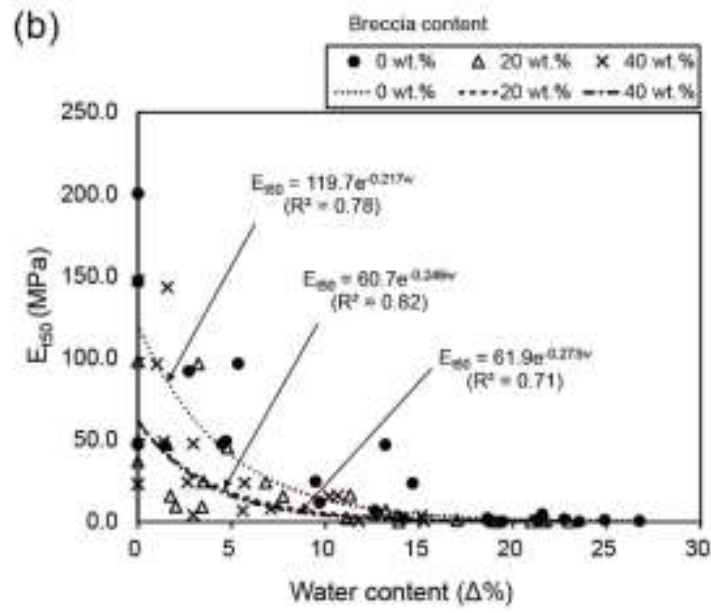

Figure 15. Relationships between (a) the secant modulus at $50 \%$ ultimate strength $\left(\mathrm{E}_{\mathrm{s} 50}\right)$ and $(\mathbf{b})$ the tangent modulus at $50 \%$ ultimate strength $\left(\mathrm{E}_{\mathrm{t} 50}\right)$ and water content with respect to three breccia contents $(0,20$, and 40 wt.\%).

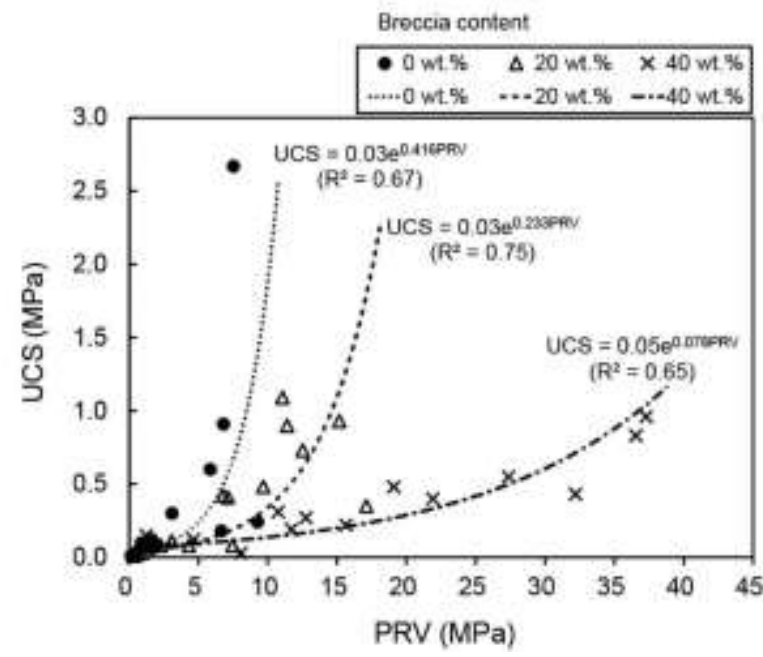

Figure 16. Correlation between unconfined compressive strength (UCS) and penetration resistance value (PRV) with respect to three levels of breccia content $(0,20$, and $40 \mathrm{wt} . \%)$. 

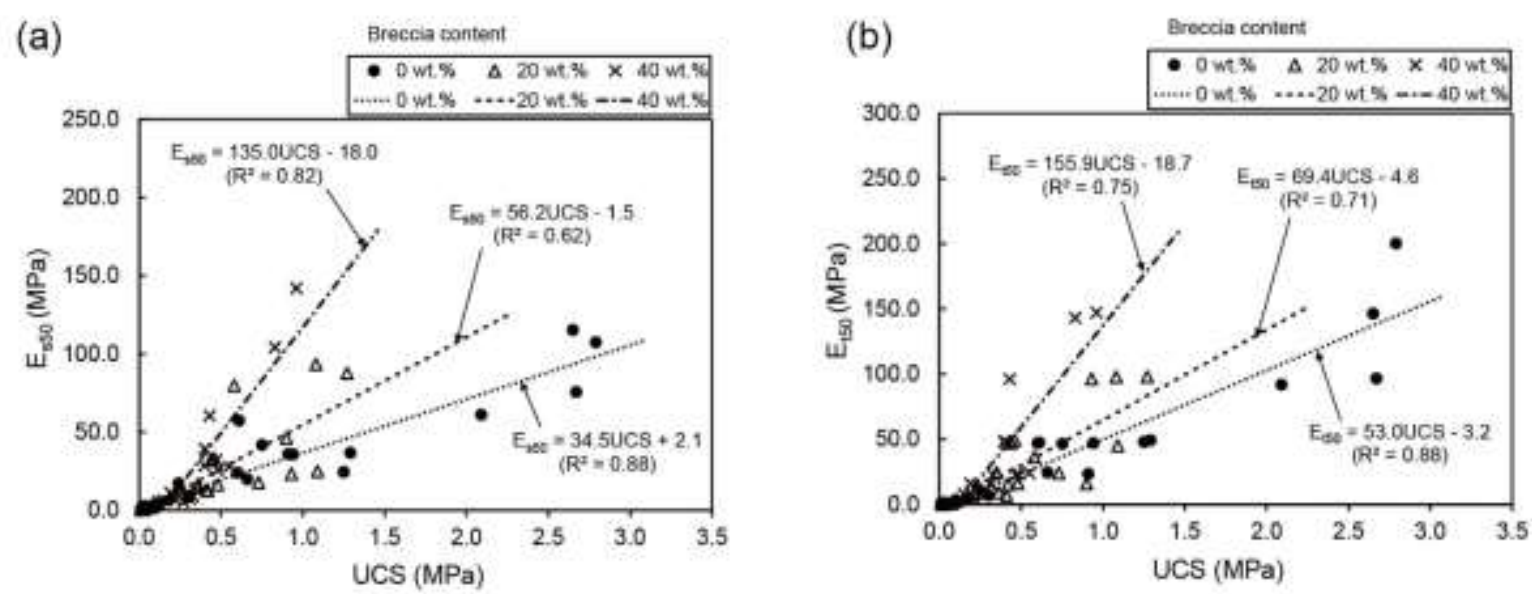

Figure 17. Relationships between (a) the secant modulus at $50 \%$ ultimate strength $\left(\mathrm{E}_{\mathrm{s} 50}\right)$ and (b) the tangent modulus at $50 \%$ ultimate strength $\left(\mathrm{E}_{\mathrm{t} 50}\right)$ and unconfined compressive strength with respect to three levels of breccia content $(0,20$, and $40 \mathrm{wt} . \%)$.

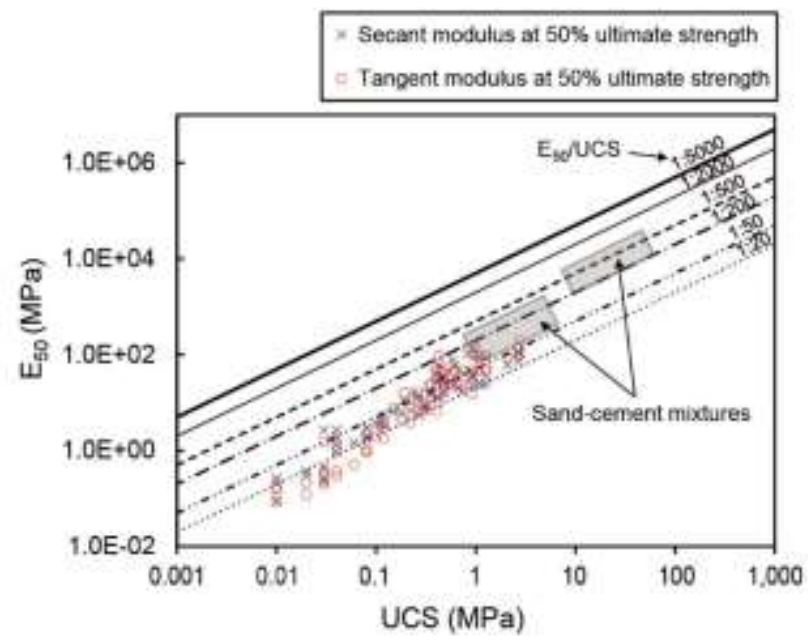

Figure 18. Relationship between elastic modulus $\left(\mathrm{E}_{\mathrm{t} 50}\right.$ and $\left.\mathrm{E}_{\mathrm{s} 50}\right)$ and unconfined compressive strength (UCS) for the studied artificial fault cores, with data for soft rocks (ratio lines) and sand-cement mixtures (shaded rectangles) shown for comparison. The artificial fault cores with UCS $<0.1 \mathrm{MPa}$ are located mostly below the 1:50 ratio line, and those with UCS $>0.1 \mathrm{MPa}$ lie mostly between the 1:20 and 1:200 ratio lines. The $\mathrm{E}_{50} / \mathrm{UCS}$ lines and shaded sand-cement data are from Kanji ${ }^{21}$, modified after Kanji and Galván ${ }^{48}$, Galván ${ }^{49}$, and Deere ${ }^{102}$. 


\begin{tabular}{|l|l|l|l|l|l|l|l|}
\hline Mineral & Quartz & Albite & Kaolinite & Microcline & Orthoclase & Chlorite & Rest \\
\hline $\begin{array}{l}\text { Content } \\
\text { (vol.\%) }\end{array}$ & 34.3 & 18.6 & 14.7 & 11.4 & 9.0 & 8.4 & 3.6 \\
\hline
\end{tabular}

Table 1. Mineral contents of the clay used for manufacturing artificial specimens, as determined by XRD analysis.

\begin{tabular}{|l|l|l|l|}
\hline Specimen No. & Breccia (wt.\%) & Sand (wt.\%) & Clay (wt.\%) \\
\hline S-1 & 0 & 0 & 100 \\
\hline S-2 & 0 & 20 & 80 \\
\hline S-3 & 0 & 40 & 60 \\
\hline S-4 & 0 & 60 & 40 \\
\hline S-5 & 20 & 0 & 80 \\
\hline S-6 & 20 & 20 & 60 \\
\hline S-7 & 20 & 40 & 40 \\
\hline S-8 & 20 & 60 & 20 \\
\hline S-9 & 40 & 0 & 60 \\
\hline S-10 & 40 & 20 & 40 \\
\hline S-11 & 40 & 40 & 20 \\
\hline
\end{tabular}

Table 2. Mixing ratios of constituent components used in each artificial specimen type.

\begin{tabular}{|l|l|l|l|l|l|l|}
\hline \multirow{2}{*}{ Specimen no. } & \multicolumn{6}{|l}{ Water content $(\boldsymbol{\omega}, \mathbf{\Delta} \% \mathbf{)}$} \\
\cline { 2 - 7 } & $\mathbf{0 ~ h}(\mathbf{a})$ & $\mathbf{1 2} \mathbf{h}(\mathbf{b})$ & $\mathbf{2 4} \mathbf{h}(\mathbf{c})$ & $\mathbf{3 6} \mathbf{h}(\mathbf{d})$ & $\mathbf{4 8} \mathbf{h}(\mathbf{e})$ & $\mathbf{7 2} \mathbf{~ h}(\mathbf{f})$ \\
\hline S-1 & 26.7 & 24.9 & 21.6 & 14.6 & 5.0 & 0.0 \\
\hline S-2 & 22.7 & 21.3 & 18.6 & 13.2 & 2.7 & 0.0 \\
\hline S-3 & 23.5 & 18.6 & 12.6 & 9.5 & 4.7 & 0.0 \\
\hline S-4 & 19.4 & 14.1 & 9.7 & 4.5 & 1.4 & 0.0 \\
\hline S-5 & 23.0 & 21.7 & 18.8 & 13.2 & 3.5 & 0.0 \\
\hline S-6 & 21.0 & 17.0 & 11.3 & 6.8 & 3.2 & 0.0 \\
\hline S-7 & 19.1 & 13.8 & 7.7 & 4.8 & 1.7 & 0.0 \\
\hline S-8 & 13.9 & 11.1 & 3.4 & 2.0 & 1.5 & 0.0 \\
\hline S-9 & 21.6 & 15.1 & 10.2 & 5.6 & 3.0 & 0.0 \\
\hline S-10 & 15.2 & 10.7 & 5.7 & 2.6 & 1.4 & 0.0 \\
\hline S-11 & 11.8 & 7.1 & 3.0 & 1.6 & 1.0 & 0.0 \\
\hline
\end{tabular}

Table 3. Water contents of specimens according to drying time. Drying times are as indicated, varying between 0 and $72 \mathrm{~h}$, with specimen sets being denoted by (a) to (f), respectively. As the water content ( $\omega$ ) at each drying interval was calculated from the specimen dried for $72 \mathrm{~h}$, water contents were expressed as the difference $(\Delta \%)$ with the water content of that specimen. 


\begin{tabular}{|c|c|c|c|c|c|c|c|c|c|c|c|c|c|c|c|c|c|c|}
\hline \multirow{2}{*}{$\begin{array}{l}\text { Specimen } \\
\text { no. }\end{array}$} & \multicolumn{6}{|c|}{ UCS (MPa) } & \multicolumn{6}{|c|}{$\mathbf{E}_{\mathbf{s} 50}$} & \multicolumn{6}{|c|}{$\mathbf{E}_{\mathbf{t 5 0}}$} \\
\hline & $\mathbf{a}$ & b & c & d & e & f & $\mathbf{a}$ & $\mathbf{b}$ & c & d & e & f & $\mathbf{a}$ & b & c & d & e & $\mathbf{f}$ \\
\hline S-1 & 0.06 & 0.08 & 0.18 & 0.91 & 2.67 & 2.79 & 1.48 & 2.95 & 6.29 & 35.77 & 75.66 & 107.55 & 0.52 & 0.94 & 4.50 & 23.46 & 96.50 & 200.31 \\
\hline $\mathrm{S}-2$ & 0.03 & 0.04 & 0.10 & 0.60 & 2.09 & 2.65 & 2.69 & 2.70 & 3.68 & 24.03 & 61.13 & 115.30 & 1.52 & 1.26 & 2.02 & 46.91 & 91.91 & 146.49 \\
\hline S-3 & 0.01 & 0.04 & 0.30 & 0.66 & 1.29 & 1.25 & 0.09 & 0.95 & 8.56 & 19.91 & 36.70 & 24.44 & 0.09 & 0.99 & 6.83 & 24.47 & 49.26 & 48.02 \\
\hline S-4 & 0.01 & 0.12 & 0.24 & 0.61 & 0.75 & 0.94 & 0.21 & 3.36 & 17.23 & 57.37 & 41.71 & 35.71 & 0.17 & 1.81 & 11.66 & 47.41 & 46.59 & 47.07 \\
\hline$S-5$ & 0.04 & 0.04 & 0.08 & 0.41 & 0.35 & 0.46 & 1.93 & 1.34 & 1.97 & 12.87 & 14.82 & 33.12 & 0.30 & 0.38 & 1.03 & 6.73 & 24.47 & 49.49 \\
\hline S-6 & 0.02 & 0.08 & 0.48 & 0.73 & 0.93 & 1.08 & 0.37 & 1.81 & 16.31 & 17.73 & 23.30 & 93.31 & 0.22 & 1.02 & 16.09 & 23.94 & 96.43 & 97.75 \\
\hline S-7 & 0.01 & 0.11 & 0.42 & 1.09 & 0.90 & 1.27 & 0.27 & 3.78 & 12.49 & 24.90 & 45.99 & 87.55 & 0.16 & 3.36 & 15.39 & 45.06 & 15.74 & 97.81 \\
\hline S-8 & 0.03 & 0.08 & 0.26 & 0.36 & 0.44 & 0.58 & 0.26 & 3.00 & 13.73 & 16.56 & 32.32 & 79.81 & 0.20 & 2.18 & 9.33 & 9.08 & 47.18 & 36.56 \\
\hline S-9 & 0.02 & 0.12 & 0.31 & 0.27 & 0.22 & 0.33 & 0.30 & 5.56 & 7.18 & 5.47 & 6.74 & 9.01 & 0.12 & 3.61 & 15.37 & 6.78 & 3.89 & 22.67 \\
\hline S-10 & 0.03 & 0.19 & 0.48 & 0.55 & 0.40 & 0.47 & 0.45 & 11.26 & 25.60 & 27.88 & 28.52 & 32.09 & 0.31 & 16.04 & 23.53 & 24.05 & 48.72 & 23.08 \\
\hline S-11 & 0.03 & 0.15 & 0.40 & 0.43 & 0.83 & 0.96 & 0.22 & 6.47 & 39.16 & 60.41 & 104.18 & 141.96 & 0.37 & 7.84 & 47.60 & 96.17 & 143.14 & 147.09 \\
\hline
\end{tabular}

Table 4. Values of UCS, $E_{\mathrm{s} 50}$, and $\mathrm{E}_{\mathrm{t} 50}$ determined from stress-strain curves for each specimen. $\mathrm{E}_{\mathrm{s} 50}$ is the secant modulus at 50\% ultimate strength, and $\mathrm{E}_{\mathrm{t} 50}$ is the tangent modulus at 50\% ultimate strength.

\begin{tabular}{|l|l|l|l|l|l|l|}
\hline \multirow{2}{*}{ Specimen no. } & \multicolumn{7}{|c|}{ Penetration resistance value (MPa) } \\
\cline { 2 - 8 } & a & b & c & d & e & f \\
\hline S-1 & 1.69 & 1.96 & 6.64 & 6.80 & 7.52 & - \\
\hline S-2 & 0.50 & 0.66 & 0.88 & 5.85 & - & \\
\hline S-3 & 0.14 & 0.67 & 3.09 & - & & - \\
\hline S-4 & 0.15 & 1.64 & 9.27 & - & - & - \\
\hline S-5 & 0.49 & 0.49 & 2.28 & 7.13 & 17.11 & \\
\hline S-6 & 0.50 & 7.46 & 9.67 & 12.52 & 15.16 & - \\
\hline S-7 & 0.31 & 3.06 & 6.77 & 11.06 & 11.40 & - \\
\hline S-8 & 0.99 & 4.31 & - & - & - & - \\
\hline S-9 & 0.70 & 4.67 & 10.76 & 12.76 & 15.64 & - \\
\hline S-10 & 8.08 & 11.70 & 19.09 & 27.37 & - & - \\
\hline S-11 & 1.23 & 21.90 & 32.20 & 36.55 & 37.29 & - \\
\hline
\end{tabular}

Table 5. Penetration resistance values determined for the tested specimens. Missing values are from specimens in which fracturing occurred during penetration testing.

\begin{tabular}{|l|l|l|l|l|}
\hline \multirow{2}{*}{ Parameter } & \multicolumn{3}{l|}{ Breccia content (wt.\%) } \\
\cline { 3 - 5 } \multicolumn{2}{|l|}{} & $\mathbf{0}$ & $\mathbf{2 0}$ & $\mathbf{4 0}$ \\
\hline \multirow{2}{*}{ Number of specimens } & 24 & 24 & 18 \\
\hline \multirow{3}{*}{$\begin{array}{l}\text { UCS value } \\
\text { MPa })\end{array}$} & Minimum & 0.01 & 0.01 & 0.02 \\
\cline { 2 - 5 } & Maximum & 2.79 & 1.27 & 0.96 \\
\cline { 2 - 5 } & Mean & 0.77 & 0.43 & 0.34 \\
\cline { 2 - 5 } & Standard deviation & 0.89 & 0.38 & 0.25 \\
\hline
\end{tabular}

Table 6. UCS values of artificial fault cores for breccia contents of 0,20 , and $40 \mathrm{wt} . \%$. 


\begin{tabular}{|c|c|c|c|c|}
\hline \multicolumn{2}{|c|}{ Parameter } & \multicolumn{3}{|c|}{ Breccia content (wt.\%) } \\
\hline & & \multirow{2}{*}{$\begin{array}{l}\text { 0 } \\
24 \\
\end{array}$} & \multirow{3}{*}{$\begin{array}{l}\mathbf{2 0} \\
24 \\
0.3 \\
\end{array}$} & \multirow{3}{*}{$\begin{array}{l}\mathbf{4 0} \\
18 \\
0.2 \\
\end{array}$} \\
\hline Numbe & ens & & & \\
\hline \multirow{4}{*}{$\begin{array}{l}\mathrm{E}_{\mathrm{s} 50} \\
(\mathrm{MPa})\end{array}$} & Minimum & 0.1 & & \\
\hline & Maximum & 115.3 & 93.3 & 142.0 \\
\hline & Mean & 28.6 & 22.5 & 28.5 \\
\hline & Standard deviation & 32.7 & 27.1 & 37.5 \\
\hline \multirow{4}{*}{$\begin{array}{l}\mathrm{E}_{\mathrm{t} 50} \\
\text { (MPa) }\end{array}$} & Minimum & 0.1 & 0.2 & 0.1 \\
\hline & Maximum & 200.3 & 97.8 & 147.1 \\
\hline & Mean & 37.5 & 25.0 & 35.0 \\
\hline & Standard deviation & 50.2 & 31.4 & 45.2 \\
\hline
\end{tabular}

Table 7. Elastic modulus ( $\mathrm{E}_{\mathrm{s} 50}$ and $\left.\mathrm{E}_{\mathrm{t} 50}\right)$ of artificial fault core for breccia contents of 0,20 , and 40 wt.\%.

\begin{tabular}{|c|c|c|c|}
\hline \multirow{2}{*}{$\begin{array}{l}\text { Mechanical } \\
\text { properties }\end{array}$} & \multicolumn{3}{|l|}{ Breccia content (wt.\%) } \\
\hline & 0 & 20 & 40 \\
\hline $\mathrm{UCS}(\mathrm{MPa})$ & $\begin{array}{l}U C S=2.1 e^{-0.166 \omega} \\
\left(\mathrm{R}^{2}=0.74\right)\end{array}$ & $\begin{array}{l}U C S=0.9 e^{-0.153 \omega} \\
\left(\mathrm{R}^{2}=0.73\right)\end{array}$ & $\begin{array}{l}U C S=0.6 e^{-0.157 \omega} \\
\left(\mathrm{R}^{2}=0.75\right)\end{array}$ \\
\hline $\begin{array}{l}\text { Elastic modulus } \\
(\mathrm{MPa})\end{array}$ & $\begin{array}{l}E_{S 50}=79.6 e^{-0.174 \omega} \\
\left(\mathrm{R}^{2}=0.68\right) \\
E_{t 50}=119.7 e^{-0.217 \omega} \\
\left(\mathrm{R}^{2}=0.78\right)\end{array}$ & $\begin{array}{l}E_{s 50}=49.1 e^{-0.197 \omega} \\
\left(\mathrm{R}^{2}=0.76\right) \\
E_{t 50}=60.7 e^{-0.246 \omega} \\
\left(\mathrm{R}^{2}=0.82\right)\end{array}$ & $\begin{array}{l}E_{s 50}=45.6 e^{-0.241 \omega} \\
\left(\mathrm{R}^{2}=0.66\right) \\
E_{t 50}=61.9 e^{-0.273 \omega} \\
\left(\mathrm{R}^{2}=0.71\right)\end{array}$ \\
\hline
\end{tabular}

Table 8. Correlations between water content and mechanical properties (UCS, $\mathrm{E}_{\mathrm{s} 50}$, and $\mathrm{E}_{\mathrm{t} 50}$ ) for breccia contents of 0,20 , and $40 \mathrm{wt} . \% . \mathrm{R}^{2}$ is the coefficient of determination, and $\omega$ is water content $(\Delta \%)$. 